\title{
CEO gender and SMEs innovativeness: evidence for Spanish businesses
}

\author{
Alfonso Expósito $^{1}$ (D) - Amparo Sanchis-Llopis ${ }^{2}$ (D) - Juan A. Sanchis-Llopis ${ }^{2,3}$
}

Accepted: 17 May 2021/Published online: 30 July 2021

(C) The Author(s) 2021

\begin{abstract}
This paper analyses the role of gender of the chief executive officer (CEO) on the propensity to introduce innovations using a sample of 1405 Spanish small- and medium-sized enterprises (SMEs). We examine whether there are significant differences between female- and male-led businesses in terms of their propensity to innovate, and whether these differences may be explained by factors related to the attributes of the CEO concerning risk tolerance, self-confidence, education level and cooperative behaviour. In particular, this study tests if the linkages between these managerial attributes and the propensity to innovate are influenced by the gender of the CEO. Using a multivariate probit model (triprobit), we further investigate the role of gender on the CEO decision to simultaneously introduce product, process and organisational innovations. Our main results indicate that there are not significant differences in the propensity to introduce innovations between male- and female-run businesses when considering innovation at an aggregated level, that is, innovating in any of the three types of innovations considered. However, we obtain a higher propensity of male CEOs to introduce process innovations, as compared to their female counterparts. No significant differences by gender are found for product and organisational innovations. Additionally, results of the multivariate probit model indicate that the three innovation decisions are interdependent and should be jointly analysed. This study contributes to the scant literature regarding gender impact on firm's innovativeness with novel empirical evidence for SMEs.
\end{abstract}

Keywords Gender · SMEs · Product innovation · Process innovation · Organizational innovations $\cdot$ triprobit model

JEL classification $\mathrm{C} 35 \cdot \mathrm{J} 16 \cdot \mathrm{O} 30 \cdot \mathrm{M} 21$

Juan A. Sanchis-Llopis

sanchisl@uv.es

Extended author information available on the last page of the article 


\section{Introduction}

Innovativeness is crucial not only for maintaining competitive advantage and survival of established businesses, but also for improving their performance (Hashi \& Stojčić, 2013; Love \& Roper, 2015; Lichtenthaler, 2016; Buratti et al., 2017). ${ }^{1}$ Existing literature shows that the decision to introduce innovations is conditioned by multiple factors, including manager's set of motivations, preferences, skills, knowledge and abilities (Alegre et al., 2013; Donate \& de Pablo, 2015; Sánchez-Báez et al., 2018; Expósito \& Sanchis-Llopis, 2019). Different businesses, given the same economic environment and external factors, may adopt different innovation strategies due to different perceptions of managers (Hambrick, 2007; Hambrick \& Mason, 1984). This is especially relevant in the case of SMEs, where the owner is usually the chief executive officer (CEO), and he/she is responsible for all strategic decisions, such as innovation adoption/implementation decisions. In this context, manager's gender has been considered as a factor influencing the innovative behaviour of the firm in studies such as Nissan et al. (2012), Alsos et al. (2013) and Marvel et al. (2015), among others.

However, existing knowledge on whether there is a gender gap in SMEs' innovativeness is still scant and inconclusive (Alsos et al., 2013; Buratti et al., 2017; Busolt \& Kugele, 2009; Carrasco, 2014; Link, 2017; Elam et al., 2019). ${ }^{2}$ In particular, the literature is scarce regarding the differences between male- and female-run businesses beyond the start-up stage, especially in terms of innovativeness, and on how gender influences managerial personal characteristics that may affect the propensity to implement innovations inside businesses. The aim of this paper is to fill this gap. We explore the role of gender on SMEs innovativeness, considering that gender may influence the relationship between CEOs managerial traits, such as risk-tolerance, self- confidence, educational level, and R\&D cooperative behaviour, and the propensity to implement innovations, controlling for other managerial and business characteristics. As reviewed in next section, these managerial traits have been considered in the gender literature as gender-sensitive and have been shown to foster business's innovativeness. ${ }^{3}$

Most of existing studies have focused on technological innovations, such as product and process innovations, in high-technology and manufacturing sectors,

\footnotetext{
${ }^{1}$ The link between innovation and firms' performance has been extensively analyzed in the literature, both in the case of mature market economies and in transition economies (see, e.g. Hashi \& Stojčić, 2013, and references therein, and also the works of Reçica et al., 2019; Mahmutaj Krasniqi, 2020 and Ramadani et al., 2017).

${ }^{2}$ The underrepresentation of women in entrepreneurship is well documented (Elam et al., 2019). The Global Entrepreneurship Monitor 2019/2020, one of the most relevant sources of information on entrepreneurial activity worldwide, reports that most countries included in the survey show a lower engagement of women in early-stage entrepreneurial activities (Bosma et al., 2020).

${ }^{3}$ We acknowledge the distinction between sex, as a biological category, and gender, as a social construction of feminine and masculine characteristics, which map into male and female individuals (Holmes, 2007). This distinction has been extensively discussed in some recent studies on entrepreneurship (Harrison et al., 2015; Gokta \& Gupta, 2015). Policy and research interest focus in gender, not sex, but evaluation of data by sex is the usual method to carry out gender-based analysis. In this study, we use information on the biological sex of the CEO to capture gender and to analyze gender differences between male and female CEOs. While we are aware of the complexities of gender issues and the new approaches to analyze gender identity, no additional information in our dataset allows us to capture gender identity by means of masculine and feminine traits nor to measure gender stereotypes. Therefore, the use of the CEO's biological sex as a measure of gender in this study should be considered when interpreting our findings.
} 
since they are considered to represent fields where innovation occurs. These sectors are dominated by gender segregation in favour of male entrepreneurs (Nissan et al., 2012; Strohmeyer \& Tonoyan, 2005). Therefore, non-technological innovations, such as organizational innovations, which usually require less resources and contain a lower level of technical complexity, are not typically considered when analysing gender issues (Wajcman, 2010). This approach simply ignores innovation activity in services and other female-oriented sectors (Nählinder et al., 2012; Pettersson \& Lindberg, 2013; Alsos et al., 2013). Our study also contributes to fill these gaps by considering both technological and non-technological innovations, as well as all business sectors, including those female- biased sectors, such as retail and services.

Data used in this study have been drawn from a survey regarding competitiveness of Spanish SMEs carried out in 2012. The main advantage of this survey is that, although the information is at the business level, it also includes some basic socio-demographic characteristics of the $\mathrm{CEO}$, such as gender, age, educational attainment, experience in running the business, and also some managerial traits, such as her/his willingness to undertake risky projects and her/his level of self-confidence in running the business. This information at the individual level is very valuable when it comes to the analysis of gender differences in the innovativeness behaviour of the firm. Regarding innovativeness, we consider three types of innovation, namely, product innovations, process innovations and organizational innovations.

Our empirical approach consists of using quantitative methods to explore the role of $\mathrm{CEO}$ gender on the propensity to introduce innovations, taking into account managerial attributes that have been associated with innovativeness in the existing literature, such as risk tolerance, self-confidence, educational level, and R\&D cooperative behaviour. First, a probit model is used to estimate the probability of the aggregate decision to introduce any of the three types of innovations considered in this study (product, process or organizational innovations). Second, we implement a multivariate probit model that allows for an estimation of the simultaneous probability to introduce the three types of innovations in a disaggregated way.

To anticipate our main results, we obtain that there are not significant differences in the propensity to introduce innovations between male- and female- led businesses when considering innovation at an aggregated level, that is, innovating in any of the three types of innovations: product, process and organizational innovations. However, when analysing the disaggregated decision to introduce the three types of innovations, we provide evidence supporting a higher propensity of male CEOs to introduce process innovations, as compared to their female counterparts, after controlling for a number of personal attributes and business characteristics. No significant differences by gender are found for product and organisational innovations. In addition, we find that SMEs innovativeness also depends on a number of personal attributes of the CEO, such as risk- tolerance, self-confidence, educational level, and R\&D cooperative behaviour. The influence of these managerial attributes on the propensity to innovate is robust to controlling for gender, suggesting that, in general, the factors underlying SMEs' innovativeness are irrespective of the gender of the CEO.

In summary, this study contributes to the literature in a number of ways. First, our findings provide new evidence to the scarce empirical literature dealing with the comparison between female and male-led businesses in terms of their propensity to 
introduce innovations, and thus, to the understanding of the role of gender in SMEs innovativeness. This is a relevant issue given the growing awareness that gender inequality in innovation hinders economic growth by lowering the pool of potential talents for entrepreneurship and innovation (see, e.g., Elam et al., 2019; OECD, 2006; IMF, 2013; WB, 2011). ${ }^{4}$ By including a gender perspective, our study contributes to a better understanding of the gender issues that may arise in entrepreneurship and management. In particular, by acknowledging the same ability of female and male CEOs to innovate and thereby help their companies to develop competitive advantages, we may contribute to recognise the value of women in management practice, and help to reduce prejudice towards social gender-based stereotypes that may still exist regarding female entrepreneurs. Second, most of the empirical studies use a control variable for female when undertaking comparative gender analysis (Johnsen \& McMahon, 2005; Koellinger et al., 2013; Alsos et al., 2013; Dohse et al., 2019; $\mathrm{Na} \&$ Shin, 2019), whereas in our study we go beyond this by exploring how gender may influence the linkages between managerial attributes, such as risktolerance, self-confidence, educational level, and R\&D cooperative behaviour, and the propensity to innovate. These managerial traits are usually not available in business surveys, and therefore have not been sufficiently explored as determinants of SMEs innovativeness. We use this valuable information to empirically test a number of research hypotheses related to the role of gender on SMEs innovativeness. Third, our analysis considers both technological (i.e., product and process innovations) and non-technological (i.e., organizational) innovations, as well as, all business sectors, including those female-biased sectors, such as retail and services. This also represents a significant contribution to the existing literature on innovation and CEO gender in SMEs, since most of the studies focus only on the technological dimension of innovation and on male-oriented sectors (i.e., industrial and technological sectors). By considering different types of innovation and a wide spectrum of business sectors, we aim to offer valuable information to decision makers, both in public and private spheres, for the design of the best policy mix to promote an innovative behaviour regardless the CEO gender and maximize the development of new economic opportunities. Fourth, our work also contributes to the literature analysing the possible complementarities among different types of innovation decisions by firms and the convenience to analyse them jointly (e.g., Martínez-Ros \& Labeaga, 2009; Doran, 2012; Carboni $\&$ Russu, 2018). To the best of our knowledge, none of these studies have explored the role of the gender of the $\mathrm{CEO}$ on the propensity to introduce product, process and organizational innovations.

The rest of the paper is organized as follows. Section 2 reviews the relevant literature and develop testable hypotheses. Section 3 describes the data and the variables to be used. In Sect. 4 we explain our analytical approach and discuss the main results. Finally, Sect. 5 presents concluding remarks.

\footnotetext{
${ }^{4}$ Gender issues have moved forward in national and global agendas. In spite of the general recognition that women and men should enjoy the same opportunities and be treated equally, they continue to have different roles in society, different access to resources and different skills. This different role in society, together with other cultural and institutional factors, imply the existence of a gender gap in many areas, including entrepreneurship and management, unfavourable to women.
} 


\section{Literature review and research hypotheses}

Though a significant number of studies have documented the impact of gender on business performance (Watson \& Robinson, 2003; Alsos et al., 2013; Marvel et al., 2015; among others), these have generally focused on the start-up stage of the venture, and have not paid sufficient attention to innovation activities (Alsos et al., 2013). ${ }^{5}$ Studies such as Weber and Geneste (2014), Buratti et al. (2017), Marvel et al. (2015), Dohse et al. (2019), and Na and Shin (2019), are among the scarce recent studies that have addressed how the manager's gender may affect the innovation profile of the firm. The work of Weber and Geneste (2014) documents that female business managers are less interested in financial performance than in personal welfare and self-fulfilment, what would explain a lower propensity to pursue strategic choices such as innovation activities. Buratti et al. (2017) show that, compared to male managers, females had a lower preference for risky strategies, such as innovation implementation, and a higher propensity to adopt a conservative approach. Marvel et al. (2015) using a sample of new Korean businesses, document that male entrepreneurs are more prone to apply for patents and to spend on $\mathrm{R} \& \mathrm{D}$, as compared to their female counterparts, but they also find that entrepreneur's education, firm's cooperation networks and regional location significantly influence the gender-innovation relationship.

The works of Dohse et al. (2019) and Na and Shin (2019) are two recent studies analysing gender issues in developing countries. Dohse et al. (2019), using a crosscountry database of more than 100 developing countries, compare the propensity to innovate of female managers with respect to their male counterparts, and find that the last, rather than female managers, are more likely to introduce product innovations (although they neither analyse process nor organizational innovation). Na and Shin (2019), using a sample of over 30 emerging countries, provide evidence that the gender of top managers has no significant impact on the probability to introduce either product, process nor organizational innovations. ${ }^{6}$ Therefore, the existing evidence on the role of CEO gender on business innovativeness is still inconclusive and further research is needed.

Our study is linked to several strands of the literature. In particular, to develop our conceptual model we use insights from upper echelons theory (UET) and the resourcebased view (RBV), in combination with feminist theories on gender and entrepreneurship. These different perspectives may help to explain how firms' access to different resources may contribute differently to male- and female-led SMEs innovativeness. Specifically, according to UET differences in demographic characteristics among managers (e.g., age and education) reflect differences in their underlying experiences,

\footnotetext{
${ }^{5}$ Within the field of gender entrepreneurship (Alsos et al., 2013) most of the literature has focused on the barriers faced by women to become entrepreneurs, as compared to men, especially regarding financial and social obstacles (e.g. Aristei \& Gallo, 2016; Robb \& Watson, 2012; Zolin et al., 2013; among others), as well as the different preferences and psychological traits of female entrepreneurs when deciding to start a new business (e.g. Sexton \& Bowman-Upton, 1990; Koellinger et al., 2013).

${ }^{6}$ These two studies, however, differ from our work not only in that they analyse developing countries, but also in that they only include a binary variable regarding gender and they do not have information on other managerial traits.
} 
cognitions and values, which in turn determine their strategic decisions such as the introduction of innovations (Hambrick \& Mason, 1984; Hambrick, 2007; Wang et al., 2016). Similarly, the RBV suggests that firms' innovative performance depends not only on the resources that are available to the firm (e.g., in terms of human capital or financial capital), but also on the individual-specific resources or abilities of their CEOs to manage those resources (Barney, 1991; Wernerfelt, 1984; Alvarez \& Busenitz, 2001; Wang et al., 2016). However, both the UET and the RBV have paid little attention to the issue of gender, so we draw on feminist theories and entrepreneurship literature to establish testable hypotheses on how SMEs innovativeness differ among female- and male-led businesses. Both liberal and social feminist theories are described as approaches that allow to identify those factors behind strategic decisions influenced by gender (Fischer et al., 1993; Ahl, 2006). In particular, liberal feminist theories postulate that men and women are essentially similar, so managers of any gender with similar resources (and characteristics) are equally able and are expected to have similar innovative propensities. On the other hand, social feminism theories consider that, due to the societal hierarchical structure, men and women are different, and have different perceptions and values, and that these differences will influence their attitudes and behaviour in running their businesses (Weber \& Geneste, 2014).

A third group of theories are social constructionist and poststructuralist feminist theories, which postulate that similarities and differences between men and woman are the result of cultural values, education and social interactions (Fischer et al., 1993; Ahl, 2006). Gender is a construct arising from the way society is built, leading to stereotypes about differences between men and women in attitudes, abilities and behavioural patterns. Entrepreneurship is therefore a gendered process shaping individual expectations concerning how females and males should behave (Eddleston \& Powell, 2012). In particular, if the role of women is considered as linked to the family, and women internalize those values, the approach to business of male and female entrepreneurs and how to run their businesses may differ (Brush et al., 2009). Consequently, these theories argue that the decision to undertake innovative activities is gendered, so that female-led business are less likely to introduce innovations than male ones.

In summary, according to liberal feminist theory, we should not observe any role of the CEO gender on SME innovative behaviour, and if differences by gender are observed, they are due to discrimination or structural barriers, such as unequal access to resources. However, according to social and constructionist feminist theories, gender is a socialization construct affecting managerial perceptions, behaviour and business decisions, and therefore, gender differences in innovation propensities would remain after controlling for systemic differences in specific attributes at managerial and business levels. Hence, the following research hypothesis is proposed:

Hypothesis 1: SMEs run by male CEOs will show a higher likelihood of implementing innovations of any type (product, process and/or organizational innovations) as compared to SMEs run by female managers.

In addition, we also consider that a number of CEO managerial traits, such as, risktolerance, self-confidence, level of education and R\&D cooperative behaviour will be positively associated with the introduction of innovations, and this association may be 
influenced by gender. In what follows we describe these relationships, how they relate to the innovativeness of SMEs, and how we expect gender to impact this relationship, setting our testable hypotheses.

\section{Gender, risk tolerance and innovation}

Investment in innovative activities is usually associated to high risk and uncertainty, so that managerial attitude towards risk is considered to be associated with innovativeness (March \& Shapira, 1987). The links between gender and risk tolerance have been extensively analysed and the bulk of the literature documents that male SME managers tend to register higher levels of risk taking, compared to their female counterparts. The works of Sexton and Bowman-Upton (1990), Buratti et al. (2017), Weber and Geneste (2014) and Mínguez-Vera and Marin (2011), among others, show that female managers are less willing to get involved in risky projects, compared to male managers. By contrast, other studies such as Sonfield et al. (2001), Atkinson et al. (2003) and Croson and Gneezy (2009) show that there are no significant gender differences in risk preferences between female and male managers.

However, attitude towards risk may be influenced by other personal or managerial unobservable traits, such as job personal satisfaction, perceptions of success in running the business, or external business environment (Weber \& Geneste, 2014; Dawson \& Henley, 2015). Job satisfaction and perceptions of success may differ by gender, so that female managers may be more interested in pursuing conservative and non-risky managerial strategies that allows them a time allocation to better keep a work-family balance (Hughes, 2006, Brush et al., 2009), or pursue personal welfare and selffulfilment (Weber \& Geneste, 2014). Therefore, even with similar levels of risk tolerance, female CEOs may be less prone to get involved in innovation activities, as compared to male counterparts. Therefore, we propose the following research hypotheses to be tested:

H1a: A high level of managerial risk tolerance is positively associated with the likelihood of implementing innovations of any type (product, process and/or organizational innovations) by the firm.

H1b: The positive impact of risk tolerance on the likelihood to implement innovations is stronger in SMEs run by male CEOs, as compared to those run by female counterparts.

\section{Gender, self-confidence and innovation}

Given the uncertainty and complexity associated with research and development activities, we might expect self-confidence to play an important role in the decision to innovate. Some works document that overconfident CEOs are more likely to innovate (Galasso \& Simcoe, 2011; Hirshleifer et al., 2012). On the other hand, studies such as Díaz-García and Moreno (2010) and Niederle and Vesterlund (2007) argue that overconfidence does not necessarily lead to better business results, including innovation performance. 
Existing literature has reported evidence on gender differences in self-confidence levels, in particular regarding the decision to run a business and to innovate (Moore \& Buttner, 1997; Sirec \& Mocnik, 2012). Studies, such as Bengtsson et al. (2005), Croson and Gneezy (2009), Lim and Envick (2013), and Meuleman et al. (2012) find that male managers tend to be more self-confident than their female counterparts. This could be linked to the fact that female entrepreneurs show lower perceptions regarding their managerial skills compared to men (Koellinger et al., 2013). In this sense, Casson (1982) argued that the combination of lower self-confidence and higher risk aversion reduce the propensity to innovate among female managers. Conversely, the studies of Belás et al. (2015) and Garwe and Fatoki (2012), among others, do not confirm the general statement of higher self-confidence levels among male managers. In this line, the study of Ashourizadeh et al. (2014) finds no evidence about differences in selfconfidence levels between male and female managers, though they do find that confidence may be turned toward action (e.g., innovation implementation) more easily for men than for women.

However, CEO self-confidence may also be influenced by other personal unobservable traits, so that female managers may hold a preference for running the business in a conservative non-risky way, whereas men may be more interested in running growthoriented and profitable entities, leading to different strategic behaviours by gender (Brush, 1992; Cliff, 1998; Weber \& Geneste, 2014). Therefore, even with similar levels of self-confidence, female CEOs may be less prone to undertake innovation activities, as compared to male counterparts. Hence, literature review shows that the analysis of how gender influences the relationship between CEO self-confidence and the propensity to implement product, process and/or organizational innovations needs further research. Therefore, the following hypotheses will be tested:

H2a: A high level of managerial self-confidence is positively associated with the likelihood of implementing innovations of any type (product, process and/or organizational innovations) by the firm.

$\mathrm{H} 2 \mathrm{~b}$ : The positive impact of managerial self-confidence on the likelihood to implement innovations is stronger in SMEs run by male CEOs, as compared to those run by female counterparts.

\section{Gender, educational level and innovation}

Formal education is one of the critical components of an entrepreneur's human capital, reflecting the level of managerial know-how and capabilities (Becker, 2009). Existing literature commonly shows that higher levels of education attained by business managers are usually related to greater cognitive ability to deal with complex problems and implement innovative solutions (Chen et al., 2010). Therefore, high educated CEOs are expected to be more prone to get involved in innovation implementation (Bantel \& Jackon, 1989; Barker \& Mueller, 2002; Koellinger, 2008; Olivari, 2016). Studies, such as Koellinger (2008), Chen et al. (2010) and Koo (2019) argue that higher educational levels significantly contribute towards the individual ability of the manager to conceive innovative business ideas, thus facilitating the implementation of innovation of any type within the firm. 
Regarding gender, women have on average a lower interest in the educational and training aspects related to natural sciences, technology, engineering and mathematics, which has been highlighted as a significant barrier for them to access entrepreneurial activity in high-technology sectors (Carrasco, 2014; Delmar et al., 2003; OECD, 2017). In this same line, Marvel et al. (2015) argue that there are significant differences in terms of educational background and specialisation between males and females managers. Several studies have shown that women tend to pursue studies in liberal arts to a greater extent than in technical fields, being the opposite in the case of males (Strohmeyer \& Tonoyan, 2005; Busolt \& Kugele, 2009; Walters \& McNeely, 2010). The role played by the formal education of the entrepreneur on the innovative profile of the firm is more significant in the case of new technology ventures, where male managers with specialized degrees in technological fields are more common (Sullivan \& Marvel, 2011). Hence, even with similar levels of formal education, if male CEOs hold degrees in technological fields, SMEs run by male executives may be more likely to innovate, as compared to male counterparts, or to implement different innovation strategies (in terms of product, process and/or organizational innovations). These issues have not been sufficiently investigated in the literature. Therefore, the following hypotheses will be tested:

H3a: Higher levels of educational attainment are positively associated with the likelihood of implementing innovations of any type (product, process and/or organizational innovations) by the firm.

$\mathrm{H} 3 \mathrm{~b}$ : The positive impact of a higher level of education attained by the manager on the likelihood to implement innovations is stronger in SMEs run by male CEOs, as compared to those run by female counterparts.

\section{Gender, R\&D cooperative behaviour and innovation}

Business networks play an important role in explaining the type and intensity of innovation in all business sectors, especially in SMEs, which do not usually have access to all necessary resources (e.g., financial and human capital) to successfully implement innovations (Teece, 1996; Freel \& Harrison, 2006; Carrasco, 2014). In this sense, literature shows that the establishment of external relationships with market agents, such as customers and suppliers, or with institutional and public agents, such as public administrations, research centres and universities, help to generate knowledge and competences to implement innovations within the firm (Rothwell \& Dodgson, 1991; Pittiglio et al., 2009), as well as to acquire important complementary resources (e.g., knowledge, technology) and enhance innovative learning by the manager (Teng, 2007; Carrasco, 2014; Marvel et al., 2015).

A variety of studies have found gender differences in individual networks in terms of variety of actors, gender composition, available resources and capacities, and network use (McGuire, 2000; Manolova et al., 2007; Dawson et al., 2011; Watson, 2012). However, evidence on the impact of different cooperative behaviours between male and female CEOs on the likelihood of implementing different types of innovation strategies constitutes a gap in the current literature. As postulated by theoretical arguments from social psychology and social cognitive theory, different gender 
socialization experiences, such as prior professional experience and social network ties, shape different strategic choices (Bussey \& Bandura, 1999). Women may perceive their businesses as "cooperative networks" in which business relationships are closely linked to family, societal, and personal factors, whereas men may be more interested in running profitable entities, leading to different gender strategic approaches to run the businesses (Brush, 1992; Cliff, 1998). Hence, even with similar levels of cooperative attitude, SMEs run by male executives may be more likely to implement different innovation strategies (product, process and/or organizational innovations), as compared to female counterparts. Therefore, the following hypotheses will be tested:

H4a: Manager's cooperative behaviour in R\&D activities is positively associated with the likelihood of implementing innovations of any type (product, process and/ or organizational innovations) by the firm.

H4b: The positive impact of the manager's cooperative behaviour in R\&D activities on the likelihood to implement innovations is stronger in SMEs run by male CEOs, as compared to those run by female counterparts.

An overview of our conceptual framework and hypotheses is graphically represented in Fig. 1.

\section{Data and descriptive statistics}

Data has been gathered from a survey on business competitiveness for Spanish SMEs carried out in 2012.7 The surveyed sample corresponds to businesses with less than 250 employees, with the exception of those self-employed entrepreneurs without employees, and a turnover below 50 million euros. The businesses surveyed were located in six Spanish regions, representing the southern, central and northern regions of Spain, corresponding to a $41 \%$ of Spanish SMEs in 2012. Our initial dataset corresponds to

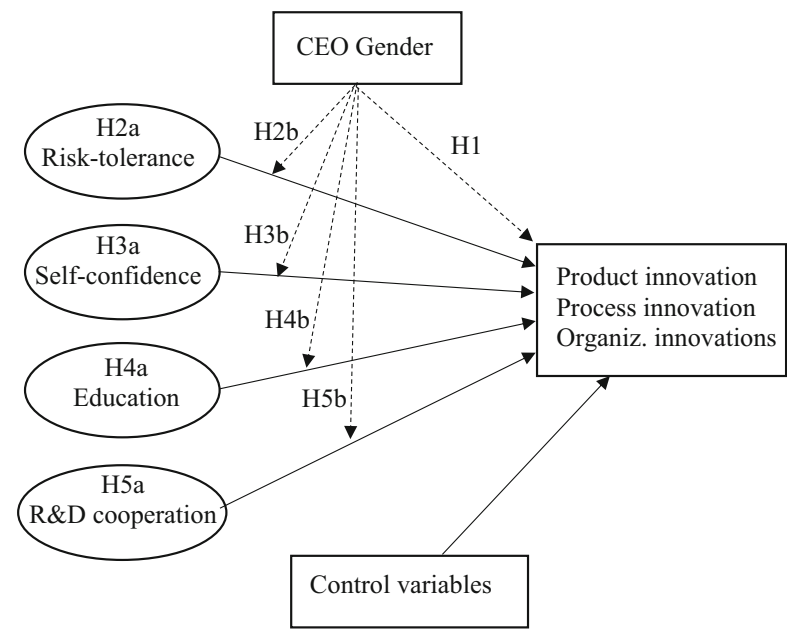

Fig. 1 Conceptual framework and hypotheses 
1425 small and medium-sized enterprises (SMEs), of which we have information regarding a single major decision-maker of the company (usually the CEO), including its gender, age, and other personal attributes, such as number of years of managerial experience, level of studies and his/her level of risk tolerance, and also information related to the business characteristics and the market where the business operates (e.g., main industrial activity, age of business, ownership form, location). Out of these 1425 SMEs, 429 are female- managed SMEs (30,1\%), whereas 996 are male-managed SMEs $(69,9 \%)$. However, since our focus is on exploring the differences in innovativeness between female- and male- managed established SMEs, following Mukhtar (2002), we include in our sample only those SMEs that can be considered as established SME, that is, those that have been operating in the market for at least 5 years and those run by CEOs with at least 5 years of managerial experience. The idea here is to be able to compare innovativeness of SMEs that have overcome the barriers and the obstacles associated with the start-up stage, which have been found to be stronger for female entrepreneurs (Koellinger et al., 2013; Aristei \& Gallo, 2016). If nascent businesses run by female are at disadvantage due to higher obstacles, by excluding these businesses from our sample, we are able to better compare innovativeness of SMEs by gender, given that, after a difficult start-up stage, entrepreneurs, both male and female, have accumulated enough experience and acquired abilities and skills, and are capable to operate their businesses with sufficient managerial practices (Mukhtar, 2002). ${ }^{7}$ Under these criteria our final sample is composed of 1,148 established SMEs, of which 828 SMEs correspond to male-managed businesses $(72,12 \%)$, and 320 SMEs are female-managed $(27,88 \%) .{ }^{8}$ Thus, in our final sample there are 2.58 men for every women who qualifies as CEO of an established SME. This ratio is in accordance to the average quote reported by official statistics (Spanish Ministry of Industry, Energy and Tourism, 2013) and similar to the ratio of other studies. ${ }^{9}$

Our focus on SMEs is founded in several factors. First, our analysis is relevant given the importance of SMEs in terms of value added, employment and the number of businesses. According to the Annual report on European SMEs 2017/2018 (European Commission, 2018), the contribution of SMEs to the non-financial business sector in Spain corresponds to $62.2 \%$ of valued added, $72,2 \%$ of employment and $99.9 \%$ of the total number of enterprises. These figures are $56.8 \%, 66.4 \%$ and $99.8 \%$, respectively, for the EU-28 Member States. Second, the control of SMEs is usually centralized and concentrated at the top of the organization, usually in the person of the CEO. This centrality enhances our confidence in the relevance and the role that gender plays in implementing and undertaking innovative activities within the firm.

\footnotetext{
${ }^{7}$ The surveyed population was stratified by sector and size following the criteria of the Central Directory of Firms (Spanish National Institute of Statistics). A 20.8\% response rate was achieved and no bias between respondents and non-respondents was perceived.

${ }^{8}$ The average age of a business in our sample at the time of the survey is 19 years (20 years for male- managed businesses, and 17 years for female managed ones). Similarly, the average length of time the CEO has been running her/his business is 19 years (20 for male-managed and 16 for female-managed ones).

${ }^{9}$ For instance, the study of Koellinger et al. (2013) analyzing gender differences in entrepreneurial propensity in 17 countries for the period 2001-2006 found that the ratio of male established entrepreneurs to female ones is 2.15 .
} 
The questionnaire was addressed to the person holding the role of the CEO in the firm, defined as the business decision-maker or the person who performs the main managerial functions within the company. There is evidence documenting that CEOs of SMEs are the key decision-makers within their organizations (Van Gills, 2005), and their decision include the main business choices, such as innovation. As stated in the existing literature, managerial perceptions shape the business strategies to a great extent (Alegre et al., 2013; Donate \& Sánchez de Pablo, 2015). In addition, self-reported information by CEOs may be used as an adequate approach to measure business innovation strategies, as it is the case of the Community Innovation Survey, and has been used in other studies (see, e.g., Madrid-Guijarro et al., 2013, and Ramadani et al., 2017). ${ }^{10}$

Data obtained from the questionnaire allows us to establish a direct relationship between gender, as the business decision-maker agent, and the business propensity to implement innovations. ${ }^{11}$ In particular, the survey includes questions regarding the innovative activities carried out by the business during the 3 years previous to the survey (period 2009-2011), as well as about other attributes at the CEO and business levels. The survey follows the OECD (2010) guidelines for the definition of innovations and distinguishes between three types of innovations: product, process and organisational innovations. Product and process innovations are usually considered as technological innovations, since technological changes generate new or transformed product/services and processes (Freeman, 1974). Organisational innovations are usually related to changes in the organisational and administrative structures of the firm. This classification of innovations has been used in other studies, such as Lichtenthaler (2016), Madrid-Guijarro et al. (2013), and Ramadani et al. (2017). Thus, using the information provided by the CEO regarding the introduction of these three types of innovations, we will construct three yes/no dummy variables to investigate gender managerial differences in innovativeness. ${ }^{12}$

In order to test the different hypotheses stated in the previous section, we use the information provided by the questionnaire to build a number of variables. In relation to personal attributes of the $\mathrm{CEO}$, the questionnaire includes not only the gender, but also information regarding some psychological traits, such as the level of risk-tolerance, self- confidence perceptions on their skills in running the business, and $R \& D$ cooperation attitudes towards other business agents and/or institutions. The questionnaire also includes other socio-demographic characteristics of the CEO, such as the level of education, age, and managerial experience. All these attributes are considered to be key factors in business decision making (Storey, 1994).

\footnotetext{
${ }^{10}$ Research performed with Global Entrepreneurship Monitor (GEM) surveys, covering a high number of countries, has also been carried out using information from self-reported personality traits of entrepreneurs and adult population, such as self-perceptions of having the skills and experience to start a business, and the fear of failure as a barrier to become an entrepreneur (Reynolds et al., 2005). Some of these self-reported traits have been analysed in the gender literature by Koellinger et al. (2013) and Alves et al. (2017). The work of Liñán et al. (2011), also using GEM data, documents the importance of self-perceptions to become entrepreneur.

${ }^{11}$ Unfortunately, the dataset lacks information regarding the number of owners or the composition of the board of directors. Therefore, we cannot analyze gender diversity among owners or within the board of directors nor gender issues regarding entrepreneurial top management teams.

${ }^{12}$ See Table A1 in Appendix for a description of all variables used in our analysis.
} 
Starting with psychological traits, and in contrast to most of existing empirical analysis on business innovativeness, we have information regarding the CEO's attitude towards risk: they are asked to answer their willingness to undertake projects of high risk and high expected returns. This is a valuable piece of information regarding the preferences of the CEO, given the importance of this attribute in determining investments, especially uncertain and risky investments such as those related to innovation, and also given the high number of studies on gender that has established differences in risk aversion as one of the main differences between male and female business managers. In fact, gender differences in risk attitudes have been explored mainly in field and laboratory experiments, with subsamples of the general population or university students. These samples may be not appropriate for drawing conclusions about gender specific-attitudes of business managers.

The questionnaire also asked CEOs several questions regarding their perceptions about their own abilities and skills to run their businesses. From this information we construct an indicator of high self-confidence which is a dummy variable taking the value of one when the CEO declares that it could expand the business with a high probability of success. In addition, CEOs are also asked about their attitudes regarding R\&D cooperation with other businesses (e.g., suppliers, customers and competitors) and also with institutions and innovation centres (e.g., universities, laboratories). From this information we construct two binary variables indicating that the CEO reports to actively cooperate in R\&D activities with other businesses and with institutions, respectively. There is a broad literature documenting the positive association between R\&D cooperation and the introduction of innovations by firms (see, e.g. Becker \& Dietz, 2004, and references therein). In addition, we also consider whether the CEO reports participating in business exhibition fairs, since this could be understood as a way to expand business opportunities and to build networking collaboration, facilitating the introduction of innovations.

In relation to other personal attributes, the questionnaire asks about the level of education attained by the manager, since as discussed in Sect. 2, higher levels of education may be related to higher propensities to introduce innovations in SMEs (Koellinger, 2008; Koo, 2019). In this respect, our analysis includes a binary variable to register if the manager has attained tertiary (university) education or not. Additionally, the age of the CEO is also a very relevant factor, since younger CEOs may be more prone to pursue innovation strategies, as compared to older ones (Barker \& Mueller, 2002). According to Chen et al. (2010), there are three reasons to expect this. First, younger managers register higher capabilities for learning and adapting their business decisions (Taylor, 1975). Second, younger managers have received their education more recently, so that their technological knowledge may be superior to the older managers, inducing them to innovativeness (Bantel \& Jackson, 1989). Third, younger managers may be more willing to undertake risky projects since their concerns about career security and stability are projected towards a long time horizon (Barker \& Mueller, 2002). Further, the experience accumulated by managers affects their willingness to undertake risky actions, such as innovative activities (Barker \& Mueller, 2002). The ability to introduce innovations depends positively on previous experience in a particular field (Shane, 2000). Previous work experience implies greater opportunities to acquire the necessary managerial knowledge for business success in general, and for innovativeness in particular (Koellinger, 2008). 
Finally, a set of other control variables has been also included in our analysis in relation to the business and market characteristics. First, involvement of the firm in innovative spending is usually shown to be directly related to innovation outcomes (Baker \& Mueller, 2002; Olivari, 2016; Koo, 2019). Although expenditure in R\&D is a common indicator for measuring innovation input, this type of expenditure is often low or absent in SMEs, therefore investment in innovation activities seems more appropriate. Hence, a variable indicating whether the firm has made spending in innovation activities during the last 3 years has been considered in our analysis. Second, we include the age of the business, measured as the number of years elapsed since its constitution (with a minimum of 5 years). Third, we control for the size of the firm by including dummy variables that account for micro, small and medium businesses according to their number of employees. This is important when analysing gender differences in innovativeness since female managers show a preference for businesses of a smaller size (Cliff, 1998). Fourth, to capture the influence of external or environmental factors, we include sectoral and regional dummy variables. The literature documents that innovative behaviour differs significantly across sectors. Regarding the industry sector, we include binary variables accounting for manufacturing, real estate and construction, commercial, and services, respectively. As for regional dummies, they correspond to the six Spanish regions included in our analysis. We rely on these sectoral and regional dummies to capture differences in the levels of technology among sectors, and also differences in the availability of resources, such as infrastructures, and policy and industrial regulations among regions. A definition of all the variables used in this study is offered in Table 6 in the Appendix.

In what follows we present some descriptive statistics for our sample of SMEs. Table 1 presents the mean and standard deviation for all variables used in our analysis, distinguishing between those businesses run by a male CEOs $(72.12 \%)$ and those run by a female ones $(27.88 \%)$. It emerges that the percentage of CEOs that introduce an innovation of any type (either product, process or organizational) is around $71 \%$ both for male and female CEOs. We also observe that product innovations is by far the most common type of innovation for both male and female CEOs (54.6\% and $52.8 \%$, respectively), followed by organizational innovations $(32.3 \%$ and $29.7 \%$, respectively). Regarding process innovation, Table 1 also reports that male CEOs introduce process innovations in a higher proportion, as compared to their female counterparts, (30.8\% and $22.2 \%$, respectively) and this difference is statistically significant. We may also observe that there are statistically significant differences between male and female CEOs in some attributes: male CEOs are older, have more years of experience in their businesses, and report a higher participation in business exhibitions than female counterparts.

Table 1 also reports the sectoral distribution of SMEs in our sample, following the general distribution of SMEs by sector and size at national level (Spanish Ministry of Industry, Energy and Touris, 2013). Almost half of the observations in our sample correspond to the services sector, where there is a higher participation of female CEOs, as compared to males. In the case of manufacturing and real estate and construction, we observe a higher proportion of male CEOs, whereas for the commercial sector the participation of male and female CEOs is similar. Regarding businesses size, most of SMEs in our sample are micro-businesses, with number of employees between 1 and 9 
Table 1 Means and standard deviations for all variables

\begin{tabular}{|c|c|c|c|c|c|}
\hline & \multicolumn{2}{|l|}{ Male } & \multicolumn{2}{|l|}{ Female } & \multirow[b]{2}{*}{ Difference } \\
\hline & Mean & s.d. & Mean & s.d. & \\
\hline \multicolumn{6}{|l|}{ Business introduction of innovations } \\
\hline $\begin{array}{l}\text { Innovation in either product, process or organization (any } \\
\text { of the } 3 \text { types). }\end{array}$ & 0.7077 & 0.455 & 0.7094 & 0.454 & -0.0017 \\
\hline Product innovation & 0.5459 & 0.498 & 0.5281 & 0.499 & 0.0178 \\
\hline Process innovation & 0.3080 & 0.461 & 0.2219 & 0.416 & $0.0861 * * *$ \\
\hline Organizational innovation & 0.3237 & 0.468 & 0.2969 & 0.457 & 0.0268 \\
\hline \multicolumn{6}{|l|}{ CEO personal traits } \\
\hline High risk-tolerance & 0.1196 & 0.324 & 0.1094 & 0.312 & 0.0102 \\
\hline High self-confidence & 0.4155 & 0.493 & 0.4031 & 0.491 & 0.0119 \\
\hline Tertiary education & 0.4698 & 0.499 & 0.4844 & 0.500 & -0.0146 \\
\hline$R \& D$ cooperation with other businesses & 0.2415 & 0.428 & 0.2219 & 0.416 & 0.0196 \\
\hline$R \& D$ cooperation with institutions & 0.1510 & 0.358 & 0.1281 & 0.334 & 0.023 \\
\hline Participation in business exhibitions & 0.7621 & 0.426 & 0.6750 & 0.469 & $0.0871 * * *$ \\
\hline Age of the entrepreneur & 49.328 & 9.568 & 45.759 & 8.477 & $3.569 * * *$ \\
\hline Managerial experience & 20.294 & 9.600 & 16.240 & 7.996 & $4.054 * * *$ \\
\hline \multicolumn{6}{|l|}{ Business characteristics } \\
\hline Involvement in innovative spending & 0.7246 & 0.446 & 0.7218 & 0.448 & 0.0028 \\
\hline Age of Business & 20.268 & 14.345 & 17.658 & 11.292 & $2.61 * * *$ \\
\hline Micro business (1-9 employees) & 0.8563 & 0.351 & 0.9000 & 0.300 & $-0.0437 * *$ \\
\hline Small business (10-49 employees) & 0.1244 & 0.330 & 0.0844 & 0.278 & $0.0404^{*}$ \\
\hline Medium business (50-250 employees) & 0.0193 & 0.137 & 0.0156 & 0.124 & 0.0037 \\
\hline \multicolumn{6}{|l|}{ Business sector } \\
\hline Manufacturing & 0.1184 & 0.323 & 0.1062 & 0.308 & 0.0122 \\
\hline Real estate and construction & 0.1655 & 0.371 & 0.1344 & 0.341 & 0.0311 \\
\hline Commercial & 0.2681 & 0.443 & 0.2688 & 0.444 & -0.0007 \\
\hline Services & 0.4481 & 0.497 & 0.4906 & 0.500 & -0.0425 \\
\hline Number of observations & 828 & & 320 & & \\
\hline
\end{tabular}

Note: $* * *, * *$ and $*$ indicate that the difference between male and female mean is significant at the $1 \%, 5 \%$ and $10 \%$ levels, respectively

employees $(85.63 \%$ in the case of male CEOs, and $90 \%$ in the case of female counterparts).

Finally, Table A2 in the Appendix presents the Pearson correlation matrix to test for multicollinearity. By inspection, correlations between the pairs is low and not significant. We observe that none of the correlation coefficients is higher than 0.8 , so that we may conclude that our empirical approach is free of multicollinearity concerns. In addition, Table 7 also provides information regarding the Variance Inflation Factor (VIF) test. All VIFs values are lower (or equal) than 2, indicating that the results are not biased due to multicollinearity. 


\section{Model specification and results}

\section{Model specification}

In order to test our proposed hypotheses, we proceed in two steps. In the first step, a probit model specification estimates the determinants of the aggregate decision to introduce innovations of any type, i.e., product, process or organizational innovation, by the SME. This specification is presented as follows,

$$
\text { Innovation }_{i}= \begin{cases}1 & \text { if } \beta_{0}+\beta_{1} X_{i}+\beta_{2} Z_{i}+u_{i} \geq 0 \\ 0 & \text { otherwise }\end{cases}
$$

where $i$ refers to the SME; the variable Innovation is a binary variable that takes value 1 if the CEO has introduced any of the three types of innovations in the last 3 years, i.e., either a product, a process or organizational innovation; $X i$ is a vector of personal traits that includes the gender of the CEO and other managerial attributes (risk-tolerance, self- confidence, tertiary education, R\&D cooperation with other business or institutions, participation in business exhibitions, experience in managerial activities and age), and $Z i$ is a vector business characteristics that may have an effect on the decision to innovate, including the business age, size, industry and region.

A first specification of the proposed probit model only includes the gender of the CEO to capture the isolated impact of gender on the propensity to innovate. In a second model specification the rest of covariates (CEOs attributes and business characteristics) are added. Finally, a third specification accounts for interactions of the gender with the rest of attributes, thus allowing to test the hypotheses we have established in Sect. 2 (in particular, regarding risk-tolerance, self-confidence, tertiary education, R\&D cooperation with other businesses and institutions, and participation in business exhibitions).

In a second step we explore the possibility that CEOs may consider simultaneously the different types of innovation and therefore we jointly analyse the three types of innovation decisions: introducing new products into the market, new processes of production and organizational innovations. In order to do so, we use econometric techniques based on a multivariate probit specification that allows simultaneous innovation decisions by the CEO. In particular, a triprobit model is implemented, thus allowing for an estimation of the joint probability to introduce these three types of innovations considered in our analysis.

More formally, we estimate the following trivariate discrete choice model for the three types of innovations:

$$
\begin{aligned}
& \text { Product }_{i}=\left\{\begin{array}{l}
1 \text { if } \beta_{0}^{\text {product }}+\beta_{1}^{\text {product }} X_{i}+\beta_{2}^{\text {product }} Z_{i}+e_{i}^{\text {product }} \geq 0 \\
0 \text { othersiwe }
\end{array}\right. \\
& \text { Process }_{i}= \begin{cases}1 & \text { if } \beta_{0}^{\text {process }}+\beta_{1}^{\text {process }} X_{i}+\beta_{2}^{\text {process }} Z_{i}+e_{i}^{\text {process }} \geq 0 \\
0 & \text { othersiwe }\end{cases} \\
& \text { Organizational }_{i}= \begin{cases}1 & \text { if } \beta_{0}^{\text {organ }}+\beta_{1}^{\text {organ }} X_{i}+\beta_{2}^{\text {organ }} Z_{i}+e_{i}^{\text {organ }} \geq 0 \\
0 & \text { otherwise }\end{cases}
\end{aligned}
$$


where the three dependent variables are binary variables taking value one when the business CEO reports to have introduced product, process and organizational innovations, respectively, during the last 3 years, and cero otherwise. As covariates, we introduce the same set of variables described in Eq. (1).

The multivariate probit specification allows for systematic correlations between the choices of the different types of innovation. ${ }^{13}$ These correlations may emerge from complementarities or substitutabilities between the three forms of innovation. The existence of significant correlations would indicate that estimating separate probit specifications for each of the three innovation decisions would be inefficient and also the convenience to analyse the three innovation decisions jointly. This specification is estimated using the simulated maximum-likelihood three-equation probit models using the Geweke-Hajivassiliou-Keane (GHK) smooth recursive simulator to compute the maximum likelihood.

\section{Estimation results}

In this section we report the estimation results for the two specifications explained above. First, in Table 2 we report the probit estimation results for the first specification, where we analyse the aggregate decision to introduce any of the three types of innovations: either product, process or organizational. In column (1) we report the estimates of a basic specification that only considers the gender of the CEO, and in column (2) we expand our specification to consider the rest of attributes. Further, columns (3) to (8) correspond to specifications that parsimoniously include interaction terms of the manager's gender with the rest of attributes that, according to the literature, may differ by gender (as explained in Sect. 2).

The results shown in Table 2 suggest that gender plays no role as a determinant in the propensity to introduce innovations, since its coefficient is not statistically significant in all columns. From a feminist theoretical perspective, this result is consistent with liberal feminist theories, claiming that gender differences would vanish after controlling for differences in CEO and business attributes. In addition, our results reveal that a number of other managerial attributes are associated with a higher propensity to introduce innovations, as hypothesized in Sect. 2. In particular, regarding psychological traits, CEOs with a high risk tolerance to undertake risky projects and showing a high level of self-confidence regarding their managerial skills are significantly and positively associated with a higher propensity to introduce innovations. Thus confirming hypotheses $\mathrm{H} 1 \mathrm{a}$ and $\mathrm{H} 2 \mathrm{a}$, respectively. As regards to the considered socio-demographic traits, results show that holding a university degree, collaborating in $\mathrm{R} \& \mathrm{D}$ with other businesses and participating in business exhibitions are all significantly and positively related to the propensity to introduce innovations, therefore confirming hypotheses H3a and H4a. Conversely, the age of the CEO is significantly and negatively associated to the innovation

\footnotetext{
${ }^{13}$ It is worth noting that the specified models do not impose that the three decisions are necessarily interrelated, but allows all possible decision combinations in the sense that some firms' implement different innovation decisions.
} 


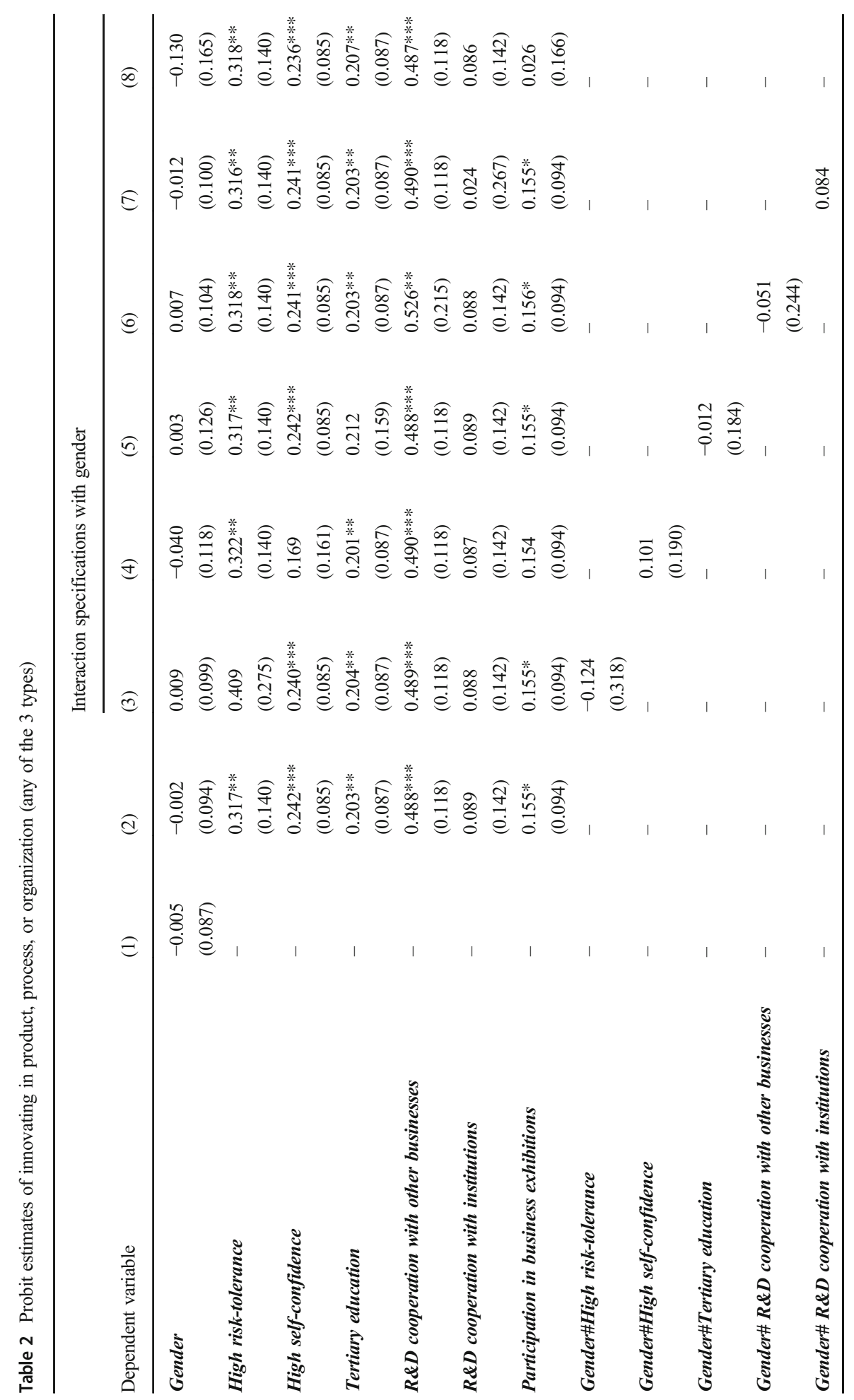




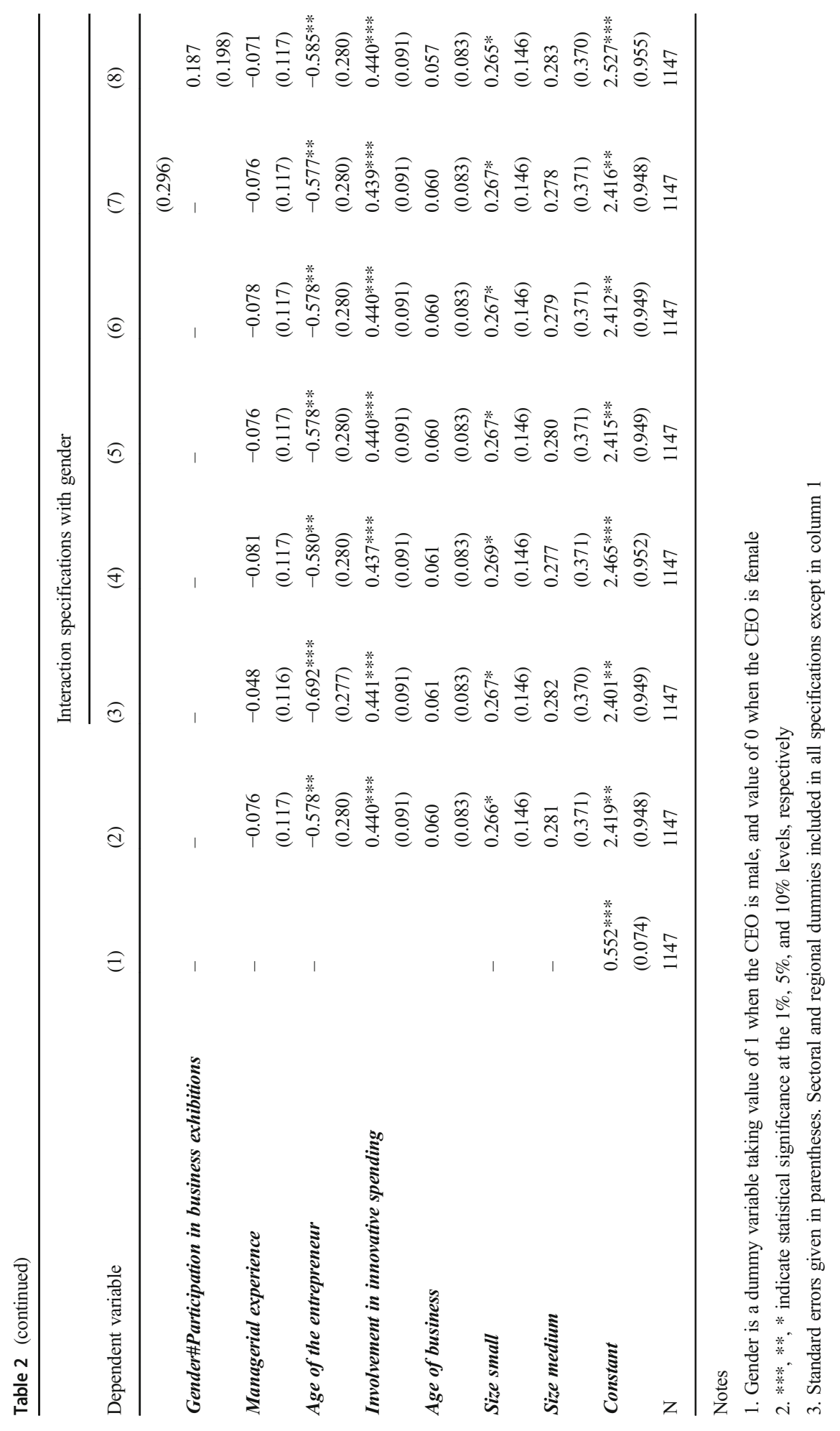


propensity in SMEs. With respect to the variable measuring if the business has been involved in innovation spending in the last 3 years, estimated coefficients show a significant positive impact on the propensity to introduce innovations by the firm. Regarding the size of the business, the propensity to innovate is higher for small businesses (those with 11-50 employees), as compared to medium or to microbusinesses. To further investigate if these entrepreneurial attributes differ by gender, in columns (3)-(8), we report the results of the interactions of the manager's gender with each one of the attributes that we have assumed as gender sensitive, following our set of hypotheses in Sect. 2. It emerges that the results obtained in column (2) regarding these managerial attributes are robust to the inclusion of the different interaction terms with gender, as presented in columns (3) to (8). Our results indicate that neither of these interaction terms, nor the variable capturing the gender of the $\mathrm{CEO}$ are statistically significant in explaining the aggregate decision of the CEO to introduce innovations. These results would reject hypotheses $\mathrm{H} 1 \mathrm{~b}, \mathrm{H} 2 \mathrm{~b}, \mathrm{H} 3 \mathrm{~b}$ and H4b.

Subsequently, the three innovation decisions are analysed separately, but allowing for the potential correlations among them using a triprobit specification as explained above. In Tables 3-5 we present the results of the triprobit model for the joint decision to introduce the three types of innovations: introducing new products into the market, new processes of production, and organizational innovations. In all estimations we obtain that the correlation coefficients among the three innovation decisions are positive and statistically significant (we can never reject the null that the three correlation coefficients are jointly equal to 0 ). On the whole, these results indicate that it is appropriate to jointly analyse the three decisions. The coefficients for the covariates estimated in each decision also differ sensibly across the equations, indicating the existence of heterogeneity in the three innovations decisions and suggesting that the analysis of the disaggregated innovation types is more appropriate than the aggregated innovation decision. These results are consistent with the study of Carboni and Russu (2018) who found complementarities among product, process and organisational innovations for a sample of European firms, and also with the findings of Doran (2012) for a sample of Irish firms data.

As before, the first specification in Table 3, column (1), includes only the variable capturing the manager's gender, and in the second specification, column (2), we add the rest of variables. Results show that gender is positive and statistically significant for the decision to introduce process innovations (both in specification 1 and 2), but nonsignificant for the decision to either introduce product or organizational innovations. Thus, we obtain that male CEOs are more prone to introduce process innovations as compared to female counterparts, but also we find no difference by gender in terms of introducing product and organizational innovations. From a feminist theoretical perspective, this result is consistent with social and constructionist feminist theories, claiming that gender is a socialization construct affecting managerial behaviour, so that gender differences in process innovations would remain after controlling for differences in CEO and business attributes. These findings are only partially in line with those of $\mathrm{Na}$ and Shin (2019) for a cross-country data of emerging countries, who show that female top managers are not significantly more likely to introduce either product, process nor organizational innovations. Further, our results are in contrast to the higher 
propensity of female managers to introduce product innovations found by Dohse et al. (2019) for a large sample of developing countries. ${ }^{14}$

The rest of the CEOs traits show different impacts on the propensity to introduce the three types of innovations by the firm, although the obtained results are in general consistent with those reported in Table 2. Thus, having a high tolerance to undertake risky projects positively and significantly affects the probability to introduce organizational innovations, whereas having a high self confidence in managerial skills increases the probability to introduce technological (both product and process) innovations. Having tertiary education increases the probability to introduce organisational innovations, but it does not affect the probability to introduce technological innovations (product and process innovations). These results are therefore in line with existing literature documenting that a high level of selfconfidence and a high level of education are positively associated with innovativeness (Koellinger, 2008). R\&D cooperation with other businesses and participation in businesses exhibitions positively affect the introduction of both product and process innovations, whereas $R \& D$ cooperation with institutions increases the probability to introduce process innovations but only at a ten percent of significant level. The experience of the CEO is associated with the introduction of process innovations, and his/her age is negatively and significantly associated with a lower propensity to introduce the three types of innovations. Regarding the involvement of the firm in innovative spending, results confirm the strong, positive and significant impact on introducing innovations of any type. On the whole, these results would confirm hypotheses $\mathrm{H} 1 \mathrm{a}, \mathrm{H} 2 \mathrm{a}, \mathrm{H} 3 \mathrm{a}$ and $\mathrm{H} 4 \mathrm{a}$, offering specific information about the different impact of managerial attributes on each type of innovation.

In Tables 4 and 5 we present the results of extending, in a parsimonious way, the triprobit specification with the inclusion of interaction terms for the variable capturing the gender with those variables capturing the rest of attributes assumed to differ by gender, i.e., high risk-tolerance, high self-confidence, tertiary education, R\&D cooperation with other businesses, R\&D cooperation with institutions, and participation in business exhibitions, respectively.

Starting with the results reported in Table 4, we observe that the gender variable is positive and statistically significant for process innovations, in the three specifications, that is after including gender interaction with high risk tolerance, high self-confidence and tertiary education, respectively, and non-significant for the decision to either introduce product or organizational innovations. These results confirm the main result shown in Table 3: male CEOs are more prone to introduce process innovations as compared to female counterparts, and no significant differences by gender are found for the introduction of product and organizational innovations. In addition, we observe that the interactions terms of gender with risk tolerance, high self-confidence and tertiary education, respectively are non-significant in any of the three estimations. Further, when interacted terms are included, the corresponding managerial attribute being interacted in each specification loses its significance (with the exception of a positive

\footnotetext{
${ }^{14}$ The works of Na and Shin (2019) and Dohse et al. (2019) analyze the impact of gender using a dummy variable, and do not take into account the possibility of gender influencing the effect of other managerial attributes on the propensity to introduce innovations. Further, Dohse et al. (2019) only consider product innovations, and do not analyze the propensity to introduce process nor organizational innovations.
} 
Table 3 Triprobit estimates of product, process and organizational innovations

\begin{tabular}{|c|c|c|c|c|c|c|}
\hline \multirow[b]{2}{*}{ Dependent variable } & \multicolumn{3}{|c|}{ Specification 1} & \multicolumn{3}{|c|}{ Specification 2} \\
\hline & $\begin{array}{l}\text { Product } \\
\text { innovation }\end{array}$ & $\begin{array}{l}\text { Process } \\
\quad \text { innovation }\end{array}$ & $\begin{array}{c}\text { Organizational } \\
\text { innovation }\end{array}$ & $\begin{array}{l}\text { Product } \\
\text { innovation }\end{array}$ & $\begin{array}{l}\text { Process } \\
\quad \text { innovation }\end{array}$ & $\begin{array}{c}\text { Organizational } \\
\text { innovation }\end{array}$ \\
\hline Gender & $\begin{array}{l}0.042 \\
(0.083)\end{array}$ & $\begin{array}{l}0.276^{* * * *} \\
(0.088)\end{array}$ & $\begin{array}{l}0.058 \\
(0.086)\end{array}$ & $\begin{array}{l}0.076 \\
(0.088)\end{array}$ & $\begin{array}{l}0.232 * * \\
(0.097)\end{array}$ & $\begin{array}{l}0.070 \\
(0.090)\end{array}$ \\
\hline High risk-tolerance & & & & $\begin{array}{l}0.167 \\
(0.123)\end{array}$ & $\begin{array}{l}0.045 \\
(0.126)\end{array}$ & $\begin{array}{l}0.276^{* *} \\
(0.119)\end{array}$ \\
\hline High self-confidence & & & & $\begin{array}{l}0.169 * * \\
(0.079)\end{array}$ & $\begin{array}{l}0.188^{* *} \\
(0.085)\end{array}$ & $\begin{array}{l}0.083 \\
(0.081)\end{array}$ \\
\hline Tertiary education & & & & $\begin{array}{l}0.056 \\
(0.082)\end{array}$ & $\begin{array}{l}0.075 \\
(0.088)\end{array}$ & $\begin{array}{l}0.176^{* * *} \\
(0.083)\end{array}$ \\
\hline $\begin{array}{l}R \& D \text { cooperation with other } \\
\text { businesses }\end{array}$ & & & & $\begin{array}{l}0.353 * * * \\
(0.103)\end{array}$ & $\begin{array}{l}0.565^{* * * *} \\
(0.101)\end{array}$ & $\begin{array}{l}0.164 \\
(0.101)\end{array}$ \\
\hline$R \& D$ cooperation with institutions & & & & $\begin{array}{l}0.196 \\
(0.125)\end{array}$ & $\begin{array}{l}0.232 * \\
(0.122)\end{array}$ & $\begin{array}{l}-0.039 \\
(0.123)\end{array}$ \\
\hline Participation in business exhibitions & & & & $\begin{array}{l}0.262 * * * \\
(0.090)\end{array}$ & $\begin{array}{l}0.249^{* *} \\
(0.101)\end{array}$ & $\begin{array}{l}-0.020 \\
(0.093)\end{array}$ \\
\hline Managerial experience & & & & $\begin{array}{l}-0.142 \\
(0.110)\end{array}$ & $\begin{array}{l}0.233 * \\
(0.121)\end{array}$ & $\begin{array}{l}0.012 \\
(0.113)\end{array}$ \\
\hline Age of the entrepreneur & & & & $\begin{array}{l}-0.538^{* *} \\
(0.264)\end{array}$ & $\begin{array}{l}-0.977 * * * \\
(0.289)\end{array}$ & $\begin{array}{l}-0.593 * * \\
(0.269)\end{array}$ \\
\hline Involvement in innovative spending & & & & $\begin{array}{l}0.490 * * * \\
(0.088)\end{array}$ & $\begin{array}{l}0.438^{* * *} \\
(0.101)\end{array}$ & $\begin{array}{l}0.236 * * \\
(0.093)\end{array}$ \\
\hline Age of business & & & & $\begin{array}{l}0.033 \\
(0.077)\end{array}$ & $\begin{array}{l}0.030 \\
(0.081)\end{array}$ & $\begin{array}{l}0.099 \\
(0.078)\end{array}$ \\
\hline Size small & & & & $\begin{array}{l}0.252 * \\
(0.129)\end{array}$ & $\begin{array}{l}0.136 \\
(0.131)\end{array}$ & $\begin{array}{l}0.309^{* *} \\
(0.124)\end{array}$ \\
\hline Size medium & & & & $\begin{array}{l}0.465 \\
(0.321)\end{array}$ & $\begin{array}{l}-0.044 \\
(0.312)\end{array}$ & $\begin{array}{l}0.306 \\
(0.292)\end{array}$ \\
\hline Constant & $\begin{array}{l}0.072 \\
(0.070)\end{array}$ & $\begin{array}{l}-0.761 * * * \\
(0.076)\end{array}$ & $\begin{array}{l}-0.522 * * * \\
(0.073)\end{array}$ & $\begin{array}{l}1.992 * * \\
(0.891)\end{array}$ & $\begin{array}{l}1.864 * \\
(0.954)\end{array}$ & $\begin{array}{l}1.029 \\
(0.898)\end{array}$ \\
\hline Observations & 1,147 & & & 1,147 & & \\
\hline$\rho_{\text {product process }}$ & $\begin{array}{l}0.370^{* * * *} \\
(0.043)\end{array}$ & & & $\begin{array}{l}0.297 * * * \\
(0.055)\end{array}$ & & \\
\hline$\rho_{\text {product_organization }}$ & $\begin{array}{l}0.138^{* * * *} \\
(0.045)\end{array}$ & & & $\begin{array}{l}0.084 * \\
(0.051)\end{array}$ & & \\
\hline$\rho_{\text {process_organization }}$ & $\begin{array}{l}0.389^{* * * *} \\
(0.043)\end{array}$ & & & $\begin{array}{l}0.379 * * * \\
(0.056)\end{array}$ & & \\
\hline LR test of rho12=rho13=rho23=0: & & & & & & \\
\hline $\begin{array}{l}\operatorname{Chi}^{2}(3) \\
\operatorname{Prob}>\mathrm{Chi}^{2}\end{array}$ & $\begin{array}{l}137.218 \\
1.50 \mathrm{e}-29\end{array}$ & & & $\begin{array}{l}80.548 \\
2.342 \mathrm{e}-17\end{array}$ & & \\
\hline
\end{tabular}

Gender is a dummy variable taking value of 1 when the CEO is male, and value of 0 when the CEO is female $* * *, * *, *$ indicate statistical significance at the $1 \%, 5 \%$, and $10 \%$ levels, respectively

Standard errors given in parentheses. Sectoral and regional dummies included in Specification 2

and significant impact of high risk-tolerance on the probability to introduce organizational innovations). Estimated results regarding the rest of regressors in Table 4 are similar to those obtained and reported in Table 3. Therefore, no evidence is found to support hypotheses $\mathrm{H} 1 \mathrm{~b}, \mathrm{H} 2 \mathrm{~b}$, and $\mathrm{H} 3 \mathrm{~b}$. 
Regarding Table 5, we observe that the gender variable is positive and significant for process innovations in the specification for R\&D cooperation with other businesses, but is not significant in the specifications for $R \& D$ cooperation with institutions nor for participation in business exhibitions. In addition, we observe that the interaction of gender is significant in only two cases. In the case of R\&D cooperation with other business, the interaction term is negative and significant for organizational innovations, indicating that male CEOs that undertake R\&D cooperation with other businesses are less likely to introduce organizational innovations (compared to their female counterparts). Additionally, in the case of R\&D cooperation with institutions, we obtain that the interaction term is positive and significant for the introduction of process innovations, suggesting that R\&D cooperation with institutions enhances the probability to introduce process innovations in the case of male CEOs. These results are consistent with existing literature on the importance of establishing external collaboration with other agents as a factor fostering innovativeness (Rothwell \& Dogson, 1991; Teng, 2007; Pittiglio et al., 2009). Moreover, in each specification the corresponding managerial attribute being interacted loses its significance level in some of the equations. Thus, results only partially support hypothesis H4b. Estimates regarding the rest of regressors in Table 5 are similar to those reported in Table 3.

In summary, our findings suggest that manager's gender plays no role as a determinant in the propensity to introduce innovations when we consider the aggregate decision to introduce any of the three types of innovation: product, process or organizational. However, when the three innovation decisions are analysed separately, we obtain that male CEOs are more prone to introduce process innovations, as compared to female counterparts, and that there are no significant differences by gender with respect to the propensity to introduce product and organisational innovations, after controlling for a number of managerial and business characteristics. The higher propensity of male CEOs, as compared to female counterparts, to implement process innovations may be associated with at least two factors. First, there might exist a male education bias, that is, a men bias to choose fields of study more technically oriented and thus more likely to provide them the technical sources (know-how and skills) and favourable conditions to develop and implement process innovations (Strohmeyer \& Tonoyan, 2005; Busolt \& Kugele, 2009; Walters \& McNeely, 2010). Females traditionally focus on nonscience fields that put them at disadvantage regarding technological innovations with respect to their male counterparts (Link, 2017; Link \& Link, 1999). Second, there is a gender- specific sectoral or occupational segregation whereby female entrepreneurs are oriented towards traditional sectors and services instead of technical or technologically oriented sectors, and process innovations are less often implemented in those femaleoriented sectors/occupations (Strohmeyer \& Tonoyan, 2005; Carrasco, 2014). Unfortunately, our data do not allow us to fully control for these two factors, so that exploring the reason for these results is beyond the scope of this study, and an avenue of further research. Nevertheless, our results contribute to a better knowledge on the role played by the CEO gender on the innovative profile of the firm, thus providing valuable insight for the design of more effective policy-mixes to promote innovativeness in SMEs. National/regional innovation action plans could introduce different gender initiatives to promote more innovation potential in female-biased sectors (e.g., retail and services), maximize economic opportunities due to innovation, as well as to 


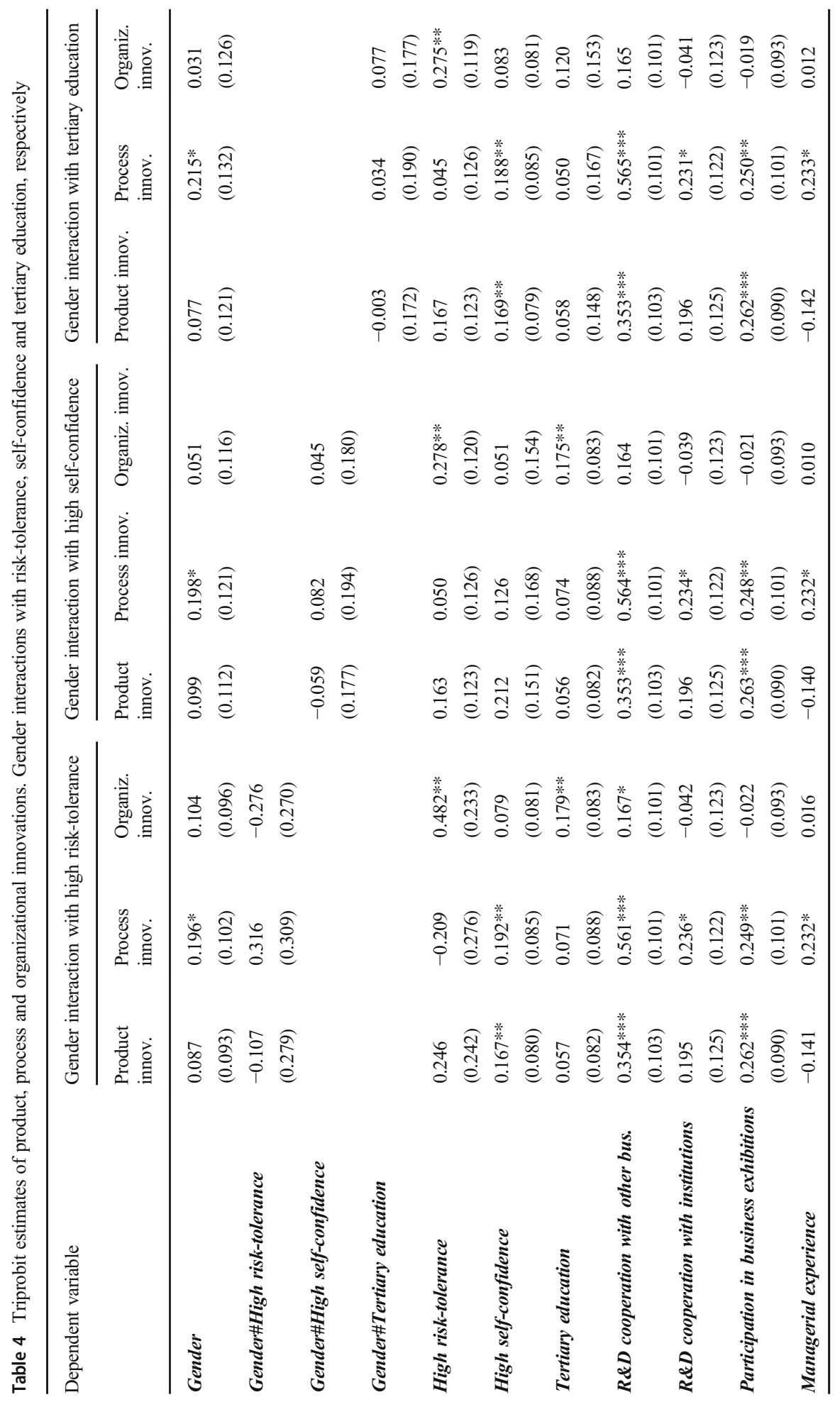




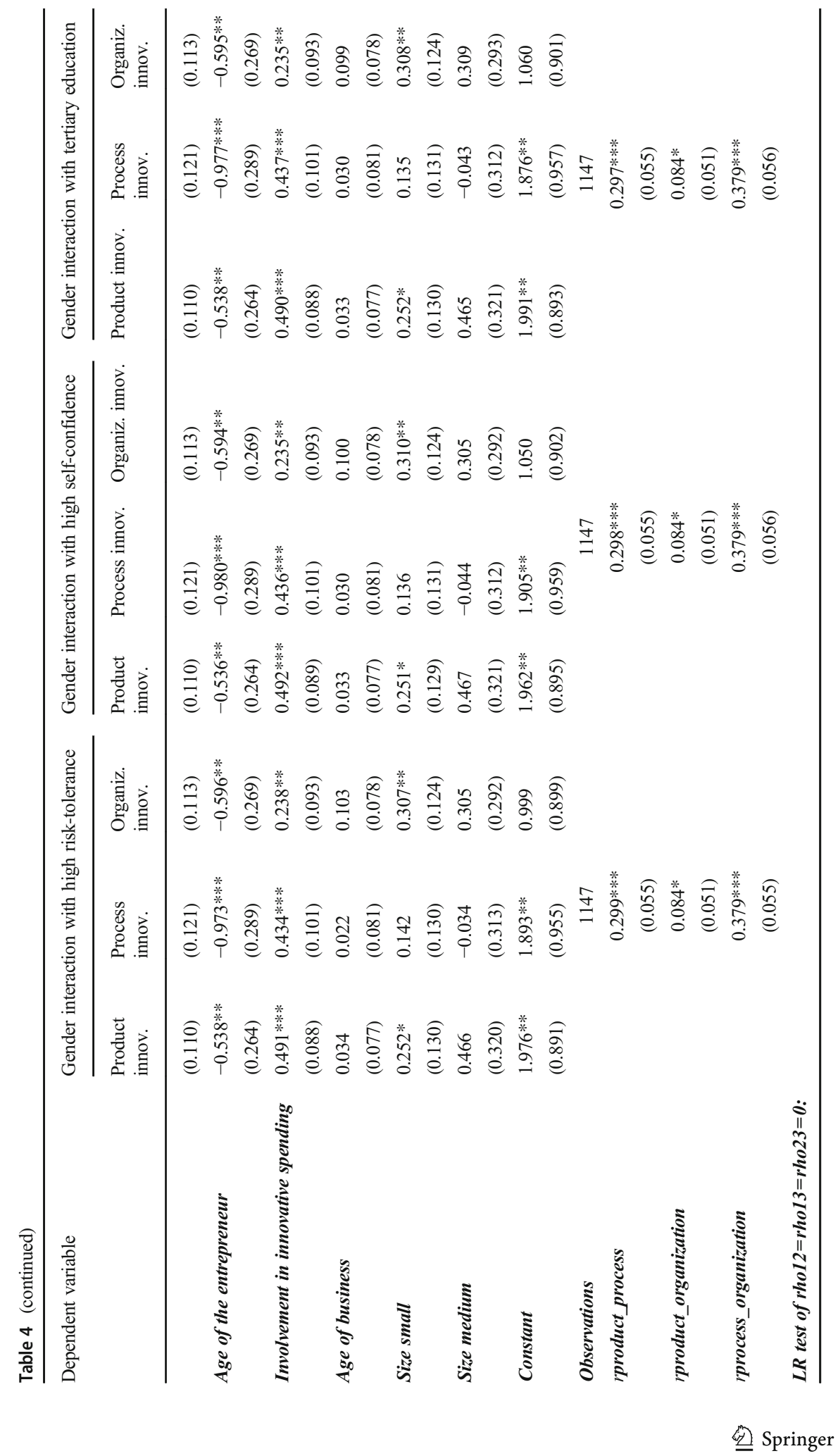




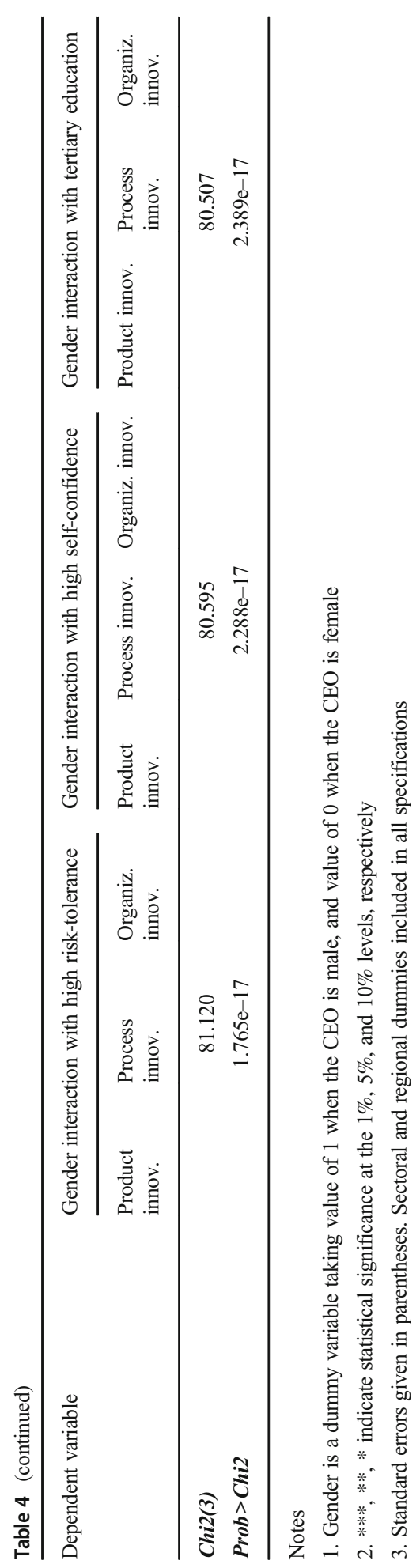

\section{包 Springer}




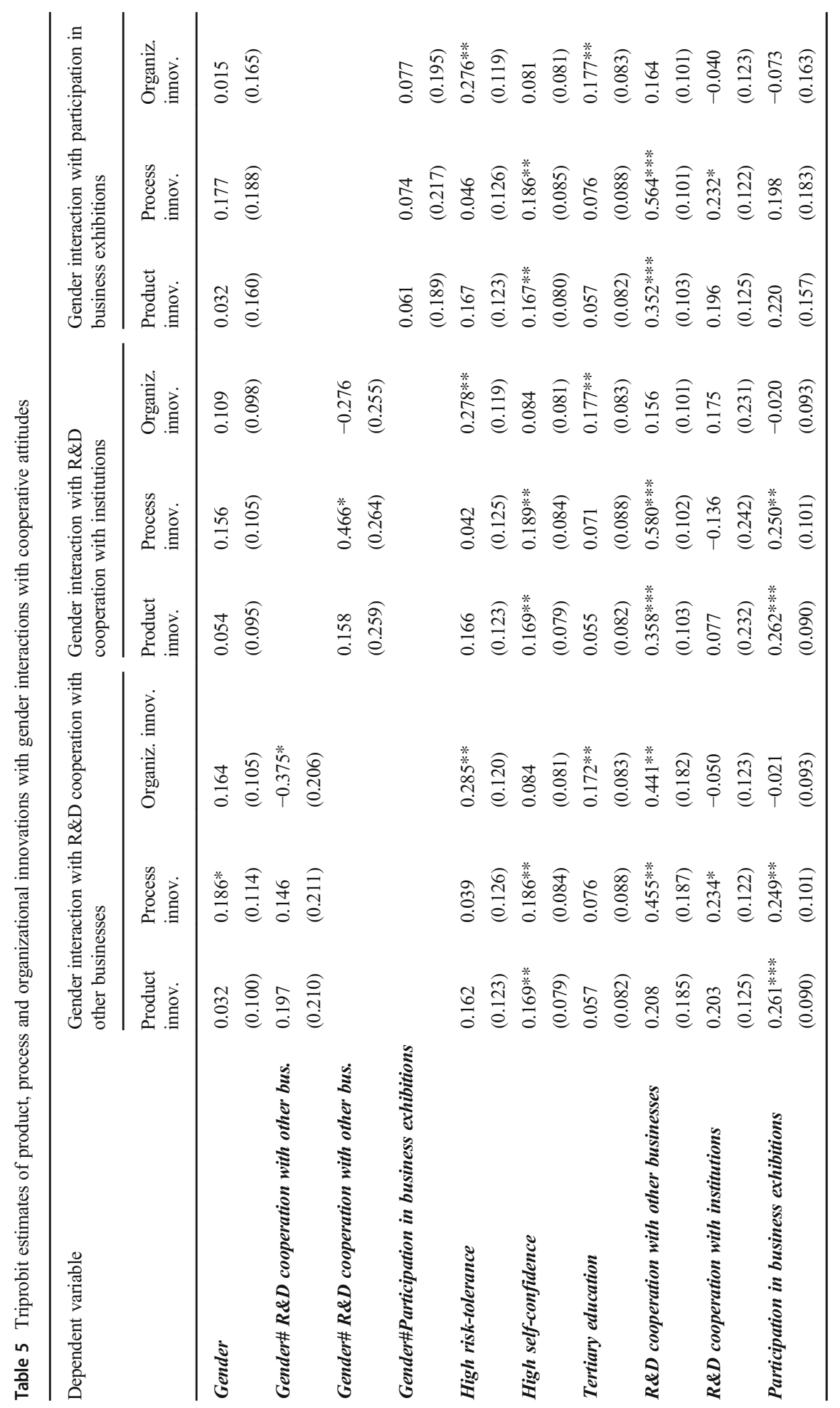




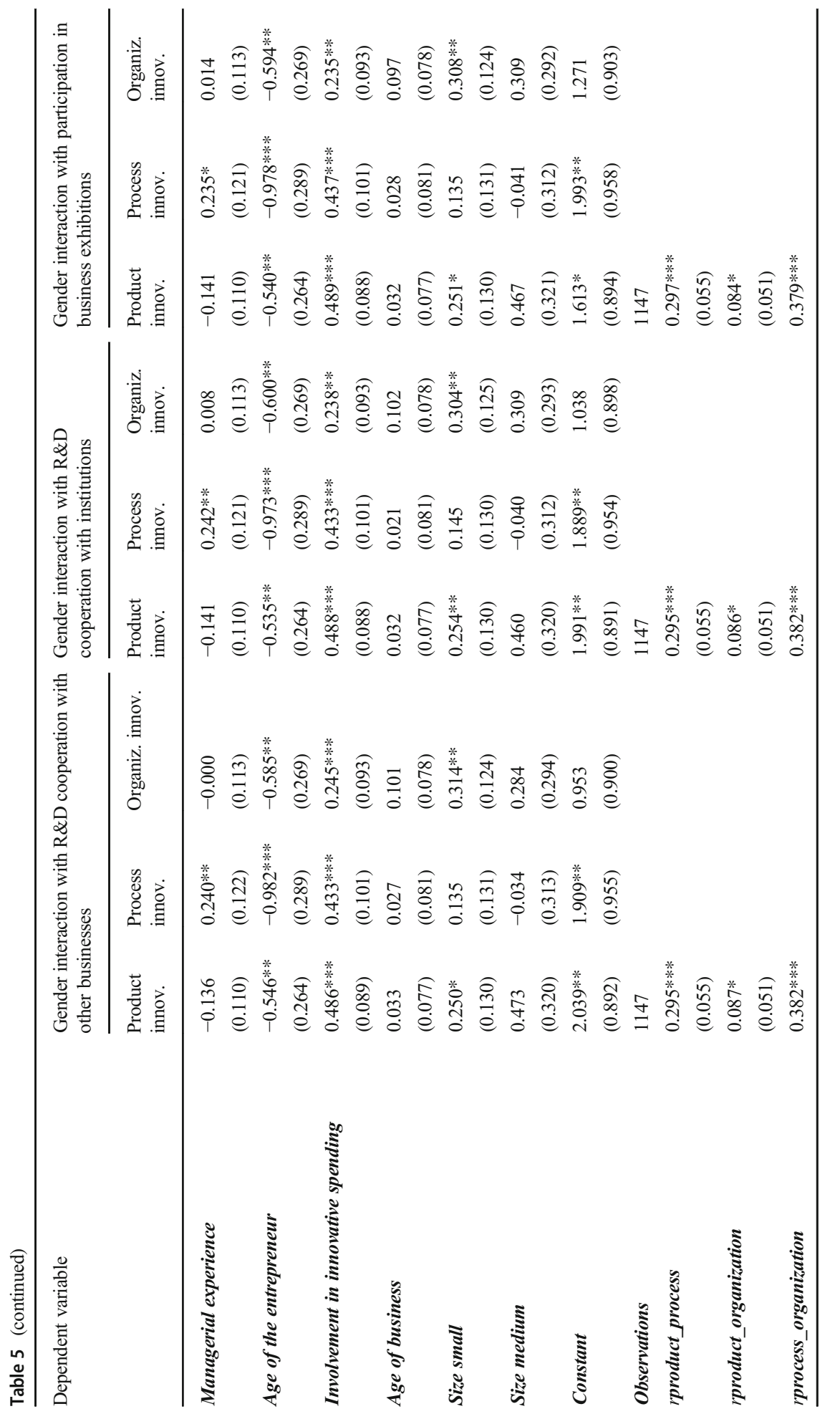




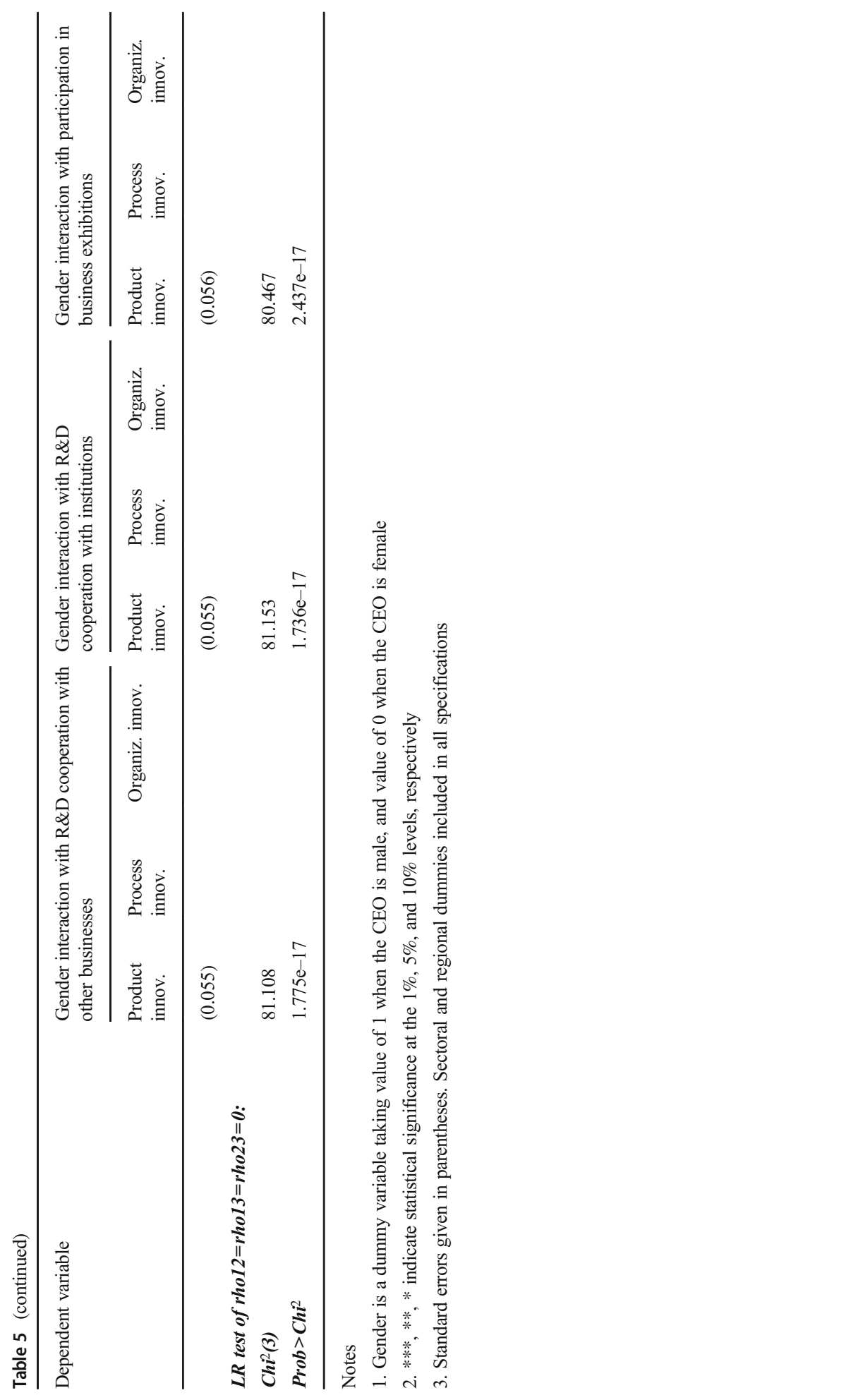


diminish potential negative impacts on the innovative profile of businesses due to gender segregation in education and in the job market.

\section{Sensitivity analysis}

The results we obtained in the previous section are robust to a number of alternative selection criteria of SMEs in our sample, as well as to the inclusion of other control variables. First, since the focus of this study is to explore the differences in innovativeness between male- and female-led businesses, we use two criteria to select the sample to analyse: we consider those businesses that have been operating in the market for at least 5 years and that are run by a CEO with at least 5 years of experience. The rationale for this selection is to focus on those established SMEs that have overcome the start-up stage. In particular, a number of papers provide evidence on the higher obstacles faced by women as compared to men when deciding to become entrepreneurs or start to operate new businesses (Koellinger et al., 2013; Aristei \& Gallo, 2016). When we consider the whole sample of SMEs provided by the survey, that is, including also those businesses in their start-up stage, similar results are obtained, especially in terms of the role of gender and interaction terms of gender with managerial attributes. Therefore, our results are robust to including also nascent businesses or new entrepreneurs.

Second, our results robustness has been tested by introducing a number of other controls in the estimated models. With this aim, we have included a dummy variable indicating involvement in R\&D spending, instead of the dummy variable indicating involvement in innovative spending (that includes R\&D expenditures and other spending related to the introduction of innovations). Results do not register any significant change. The rationale to finally introduce in our estimation the indicator of innovative spending instead of the one for $R \& D$ spending is that we are analysing not only technological innovations (i.e., product and process innovations), but also non-technological innovations, that is, organizational innovations. Therefore, a broader definition of innovative spending seems more appropriate. Additionally, the inclusion of other attributes of the manager and business, such as a dummy variable capturing the ownership structure of the SME as a limited liability company (Ltd.) and a dummy variable controlling for other levels of education (e.g., secondary education) rendered non- significant coefficients, thus not altering the estimated results.

\section{Concluding remarks}

Using a sample of Spanish SMEs, we have explored the role of gender on the propensity to introduce innovations, taking into account other managerial attributes that may be associated with innovativeness, such as risk tolerance, self-confidence, educational level, and R\&D cooperative behaviour. We have established a number of hypotheses related to role of gender in influencing the impact of managerial attributes on firm's innovativeness. In order to test our proposed hypotheses, we have proceed in two steps. First, a probit model has been used to estimate the probability of the aggregate decision to introduce any of the three types of innovations considered in this 
study (product, process or organizational innovations). Second, a multivariate probit model have been implemented to estimate the simultaneous probability to introduce the three types of innovations in a disaggregated way.

Our findings have provided evidence that male CEOs are no more likely to introduce innovations than their female counterparts when considering the aggregated decision to implement either product, process or organizational innovations. However, when analysing the disaggregated decision to introduce the three types of innovations, our results indicate a higher propensity of male CEOs to introduce process innovations, as compared to their female counterparts. No significant differences by gender are found for product and organisational innovations, suggesting that both male and female CEOs are similar regarding their propensity to introduce these types of innovations.

In addition, we have also found that SMEs innovativeness depends on a number of personal attributes of the CEO, such as risk-tolerance, self-confidence, educational level, and R\&D cooperative behaviour. These attributes, that have been less explored in business surveys due to lack of information, seem to operate in much the same way for female- and male- led businesses, suggesting that, in general, the factors underlying SMEs' innovativeness are irrespective of the gender. Finally, our results have indicated that the decision of the CEO to introduce product, process and organisational innovations are interdependent and should be jointly analysed. These complementarities among the different types of innovation should be also considered by decisionmakers in formulating overall innovation policy.

By contributing to the understanding of the role played by gender in the innovation profile of SMEs, our findings may help policy makers and practitioners in designing instruments to reduce gender inequality in innovation and maximize economic gains through innovation promotion. In fact, as pointed out by Liberda and Zajkowska (2017), a gender perspective is still missing in policies towards innovation and entrepreneurship. Our findings suggest the need of policies aimed at reducing innovation opportunities losses due to gender segregation in education and in the job market. A key implication of our research is that future research should focus on investigating those factors explaining why female CEOs are less prone to introduce process innovations as compared to their male counterparts.

Funding Open Access funding provided thanks to the CRUE-CSIC agreement with Springer Nature. Spanish Agencia Estatal de Investigación and Fondo Europeo de Desarrollo Regional (project ECO201786793-R); Generalitat Valenciana (PROMETEU/2019/095); Spanish Ministry of Economy and Competitiveness (ECO2014-55745-R); and Junta de Andalucía (P09-SEJ-4857).

Data availability Data belongs to a private project and it is not available.

\section{Declarations}

Conflicts of interest/competing interests None.

Code availability Non-applicable. 


\section{Appendix}

Table 6 Definition of variables

\begin{tabular}{|c|c|}
\hline Variable name & Definition \\
\hline Gender & $\begin{array}{l}\text { Dummy variable taking the value of } 1 \text { if the CEO of the business is male, and } \\
\text { the value of } 0 \text { if female }\end{array}$ \\
\hline Product innovation & $\begin{array}{l}\text { Dummy variable taking the value of } 1 \text { if the business has introduced any new } \\
\text { product or service during the last three years, and } 0 \text { otherwise }\end{array}$ \\
\hline Process innovation & $\begin{array}{l}\text { Dummy variable taking the value of } 1 \text { if the business has introduced any new } \\
\text { process during the last three years, and } 0 \text { otherwise }\end{array}$ \\
\hline Organizational innovation & $\begin{array}{l}\text { Dummy variable taking the value of } 1 \text { if the business has introduced any } \\
\text { organizational innovation during the last three years, and } 0 \text { otherwise }\end{array}$ \\
\hline $\begin{array}{l}\text { Innovation in any of the } \\
\text { three types }\end{array}$ & $\begin{array}{l}\text { Dummy variable taking the value of } 1 \text { if the business has introduced either a } \\
\text { product innovation, a process innovation, or an organizational innovation } \\
\text { during the last three years, and } 0 \text { otherwise }\end{array}$ \\
\hline High risk-tolerance & $\begin{array}{l}\text { Dummy taking the value of } 1 \text { if the CEO reports a high level of risk tolerance, } \\
\text { and } 0 \text { otherwise. Risk tolerance is measured as a self-reported statement of } \\
\text { having a high predisposition to undertake projects of high risk and high } \\
\text { expected returns }\end{array}$ \\
\hline
\end{tabular}

High self-confidence

Dummy taking the value of 1 if the CEO reports a high level of self-confidence, and 0 otherwise. We consider that the CEO shows a high level of self-confidence when she/he states a high probability of success in the case that she/he decided to expand the business

Tertiary education

Dummy variable taking the value of 1 if the CEO holds a university degree, and 0 otherwise

$R \& D$ cooperation with other businesses

Dummy variable taking the value of 1 if the CEO reports collaboration in R\&D with other businesses (customer, suppliers or competitors), and 0 otherwise

\section{$R \& D$ cooperation with institutions}

\section{Participation in business exhibitions}

Managerial experience

Age of the entrepreneur

Involvement in innovative spending

\section{Age of business}

Size

Region

Sector
Dummy taking the value of 1 if the CEO reports collaboration in R\&D with institutions and technology centres (universities, laboratories, etc.), and 0 otherwise

Dummy variable taking the value of 1 if the CEO reports attendance to sector business fairs, and 0 otherwise

Log of the number of years of experience of the CEO in managerial activities Log of the age of the manager

Dummy variable taking the value of 1 if the business has been involved in expenditures related to the introduction of innovations (in a broad sense, including $R \& D$ ) during the last three years, and 0 otherwise

Log of the age of the business, measured as the number of years since its founding

Three dummy variables corresponding to three business sizes according to the number of employees: 1. Micro (1-10 employees); 2. Small (11-50 employees); 3. Medium (20-250 employees)

Six dummy variables corresponding to six Spanish regions (Autonomous Communities): 1. Andalusia; 2. Extremadura; 3. Madrid; 4. Murcia; 5. Navarra; 6. Basque Country

Four dummy variables taking the following values: 1. Manufacturing; 2. Real estate and construction; 3 . Commercial; 4. Services 


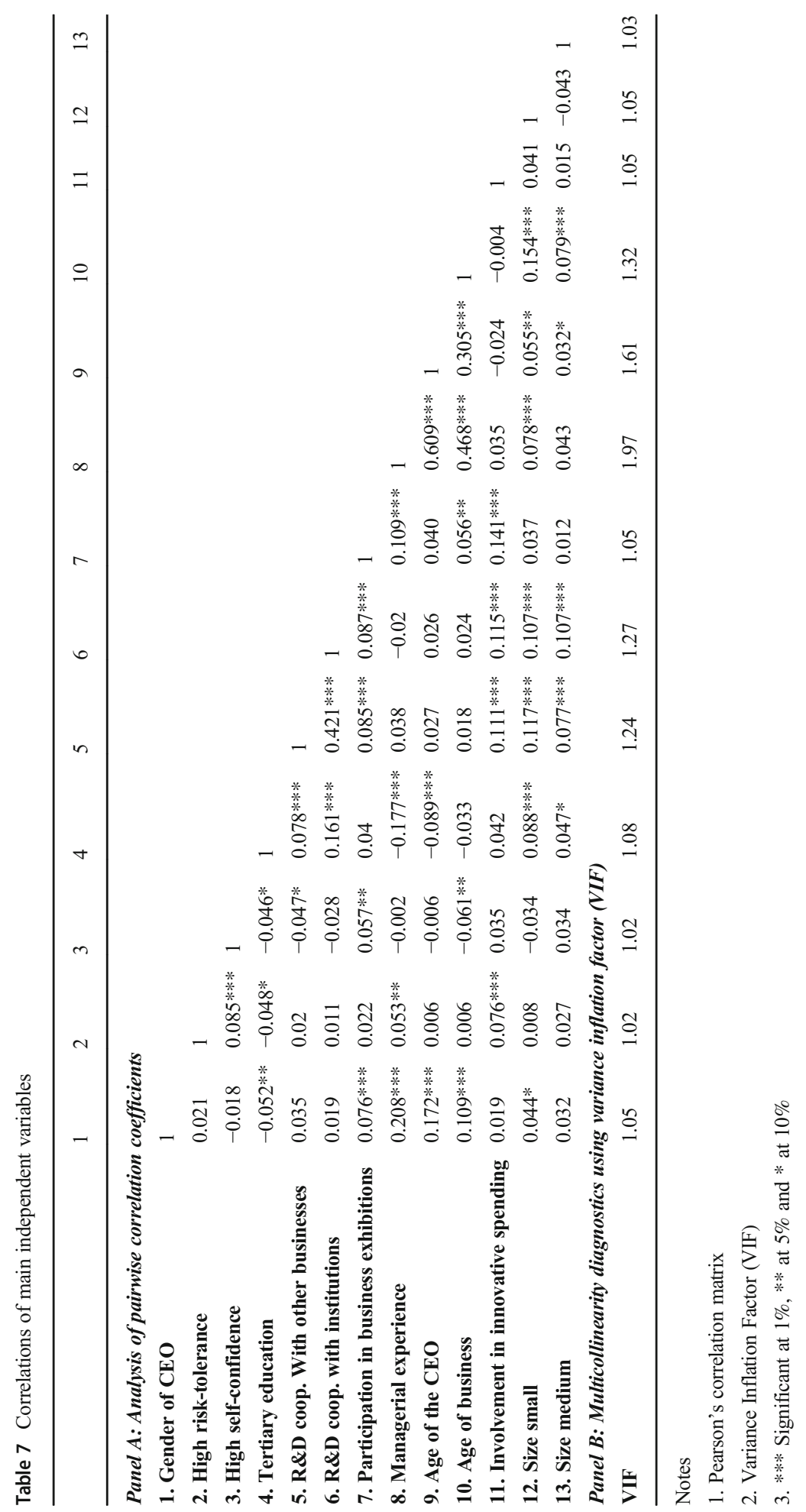


Open Access This article is licensed under a Creative Commons Attribution 4.0 International License, which permits use, sharing, adaptation, distribution and reproduction in any medium or format, as long as you give appropriate credit to the original author(s) and the source, provide a link to the Creative Commons licence, and indicate if changes were made. The images or other third party material in this article are included in the article's Creative Commons licence, unless indicated otherwise in a credit line to the material. If material is not included in the article's Creative Commons licence and your intended use is not permitted by statutory regulation or exceeds the permitted use, you will need to obtain permission directly from the copyright holder. To view a copy of this licence, visit http://creativecommons.org/licenses/by/4.0/.

\section{References}

Ahl, H. (2006). Why research on women entrepreneurs needs new directions. Entrepreneurship Theory and Practice, 30(5), 595-621.

Alegre, J., Sengupta, K., \& Lapiedra, R. (2013). Knowledge management and innovation performance in a high-tech SMEs industry. International Small Business Journal, 31(4), 454-470.

Alsos, G. A., Hytti, U., \& Ljunggren, E. (2013). Gender and innovation: State of the art and a research agenda. International Journal of Gender and Entrepreneurship, 5(3), 236-256.

Alvarez, S. A., \& Busenitz, L. W. (2001). The entrepreneurship of resource-based theory. Journal of Management, 27(6), 755-775.

Alves, M. F. R., Galina, S. V. R., Macini, N., Cagica Carvalho, L., \& Costa, T. (2017). Internationalization and innovation in nascent companies: does gender matter? Journal of Small Business and Enterprise Development, 24(4), 887-905.

Aristei, D., \& Gallo, M. (2016). Does gender matter for firms' access to credit? Evidence from international data. Finance Research Letters, 18, 67-75.

Ashourizadeh, S., Chavoushi, Z. H., \& Schøtt, T. (2014). People's confidence in innovation: A component of the entrepreneurial mindset, embedded in gender and culture, affecting entrepreneurial intention. International Journal of Entrepreneurship and Small Business, 23(1-2), 235-251.

Atkinson, S. M., Baird, S. B., \& Frye, M. B. (2003). Do female mutual fund managers manage differently? Journal of Financial Research, 26(1), 1-18.

Bantel, K. A., \& Jackson, S. E. (1989). Top management and innovations in banking: Does the composition of the top team make a difference? Strategic Management Journal, 10(S1), 107-124.

Barker, V. L., \& Mueller, G. C. (2002). CEO characteristics and firm R\&D spending. Management Science, 48(6), 782-801.

Barney, J. (1991). Firm resources and sustained competitive advantage. Journal of Management, 17(1), 99120.

Becker, G. S. (2009). Human capital: A theoretical and empirical analysis, with special reference to education. University of Chicago Press.

Becker, W., \& Dietz, J. (2004). R\&D cooperation and innovation activities of firms - evidence for the German manufacturing industry. Research Policy, 33(2), 209-223.

Belás, J., Kljunikov, A., Vojtovi, S., \& Sobeková-Májková, M. (2015). Approach of the SME entrepreneurs to financial risk management in relation to gender and level of education. Economics and Sociology, 8(4), $32-42$.

Bengtsson, C., Persson, M., \& Willenhag, P. (2005). Gender and overconfidence. Economics Letters, 86(2), 199-203.

Bosma, N., Hill, S., Ionescu-Somers, A., Kelley, D., Levie, J., \& Tarnawa, A. (2020). Global entrepreneurship monitor 2019/2020 global report. Global Entrepreneurship Research Association, London Business School.

Brush, C. G. (1992). Research on women business owners: Past trends, a new perspective and future directions. Entrepreneurship Theory and Practice, 16(4), 5-30.

Brush, C. G., De Bruin, A., \& Welter, F. (2009). A gender-aware framework for women's entrepreneurship. International Journal of Gender and Entrepreneurship, 1(1), 8-24.

Buratti, A., Cesaroni, F.M., \& Sentitu, A. (2017). Does gender matter in strategies adopted to face the economic crisis? A comparison between men and women entrepreneurs. In Entrepreneurship-development tendencies and empirical approach. IntechOpen. 
Busolt, U., \& Kugele, K. (2009). The gender innovations and research productivity gap in Europe. International Journal of Innovations and Sustainable Development. Special Issue on Gender and Sustainable Development, 4(2/3), 109.

Bussey, K., \& Bandura, A. (1999). Social cognitive theory of gender development and differentiation. Psychological Review, 106(4), 676-713.

Carboni, O. A., \& Russu, P. (2018). Complementarity in product, process, and organizational innovation decisions: Evidence from European firms. $R \& D$ Management, 48(2), 210-222.

Carrasco, I. (2014). Gender gap in innovation: An institutionalist explanation. Management Decision, 52(2), $410-424$.

Casson, M. (1982). The entrepreneur: An economic theory. Rowman \& Littlefield.

Chen, H. L., Hsu, W. T., \& Huang, Y. S. (2010). Top management team characteristics, R\&D investment and capital structure in the IT industry. Small Business Economics, 35(3), 319-333.

Cliff, J. (1998). Does one size fit all? Exploiting the relationship between attitudes towards growth, gender and business size. Journal of Business Venturing, 13, 523-442.

Croson, R., \& Gneezy, U. (2009). Gender differences in preferences. Journal of Economic Literature, 47(2), $448-474$.

Dawson, C., \& Henley, A. (2015). Gender, risk, and venture creation intentions. Journal of Small Business Management, 53(2), 501-515.

Dawson, C., Fuller-Love, N., Sinnott, E., \& O'Gorman, B. (2011). Entrepreneurs' perceptions of business networks: Does gender matter? The International Journal of Entrepreneurship and Innovation, 12(4), 271-281.

Delmar, F., Wiklund, J., \& Sjöberg, K. (2003). The involvement in self-employment among the Swedish science and technology labour force between 1990 and 2000. Institutet för tillväxtpolitiska studier (ITPS).

Díaz-García, M. C., \& Jiménez-Moreno, J. (2010). Entrepreneurial intention: The role of gender. International Entrepreneurship and Management Journal, 6(3), 261-283.

Dohse, D., Goel, R. K., \& Nelson, M. A. (2019). Female owners versus female managers: Who is better at introducing innovations? The Journal of Technology Transfer, 44(2), 520-539.

Donate, M. J., \& de Pablo, J. D. S. (2015). The role of knowledge-oriented leadership in knowledge management practices and innovation. Journal of Business Research, 68(2), 360-370.

Doran, J. (2012). Are differing forms of innovation complements or substitutes? European Journal of Innovation Management, 15(3), 351-371.

Eddleston, K. A., \& Powell, G. N. (2012). Nurturing entrepreneurs' work-family balance: A gendered perspective. Entrepreneurship Theory and Practice, 36(3), 513-541.

Elam, A. B., Brush, C. G., Greene, P. G., Baumer, B., Dean, M., \& Heavlow, R. (2019). Global entrepreneurship monitor: Women's entrepreneurship 2018/2019 report. Wellesley, M.A.

European Commission (2018). Annual report on European SMEs 2017/2018. https://publications.europa.eu/ en/publication-detail/-/publication/a435b6ed-e888-11e8-b690-01aa75ed71a1.

Expósito, A., \& Sanchis-Llopis, J. A. (2019). The relationship between types of innovation and SMEs performance: A multi-dimensional empirical assessment. Eurasian Business Review, 9(2), 115-135.

Fischer, E. M., Reuber, A. R., \& Dyke, L. S. (1993). A theoretical overview and extension of research on sex, gender and entrepreneurship. Journal of Business Venturing, 8(2), 151-168.

Freel, M. S., \& Harrison, R. T. (2006). Innovation and cooperation in the small firm sector: Evidence from 'Northern Britain'. Regional Studies, 40(4), 289-305.

Freeman, C. (1974). The economics of industrial innovation. Penguin Modern Economic Texts.

Galasso, A., \& Simcoe, T. S. (2011). CEO overconfidence and innovation. Management Science, 57(8), 1469-1484.

Garwe, D. K., \& Fatoki, O. (2012). The impact of gender on SME characteristics and access to debt finance in South Africa. Development Southern Africa, 29(3), 448-461.

Goktan, A. B., \& Gupta, V. K. (2015). Sex, gender, and individual entrepreneurial orientation: Evidence from four countries. International Entrepreneurship and Management Journal, 11(1), 95-112.

Hambrick, D. C. (2007). Upper echelons theory: An update. Academy of Management Review, 32(2), 334 343.

Hambrick, D. C., \& Mason, P. A. (1984). Upper echelons: The organization as a reflection of its top managers. Academy of Management Review, 9(2), 193-206.

Harrison, R., Leitch, C., \& McAdam, M. (2015). Breaking glass: Toward a gendered analysis of entrepreneurial leadership. Journal of Small Business Management, 53(3), 693-713.

Hashi, I., \& Stojčić, N. (2013). The impact of innovation activities on firm performance using a multi-stage model: Evidence from the community innovation survey 4. Research Policy, 42(2), 353-366. 
Hirshleifer, D., Low, A., \& Teoh, S. H. (2012). Are overconfident CEOs better innovators? The Journal of Finance, 67(4), 1457-1498.

Holmes, M. (2007). What is gender? Sage.

Hughes, K. D. (2006). Exploring motivation and success among Canadian women entrepreneurs. Journal of Small Business \& Entrepreneurship, 19(2), 107-120.

International Monetary Fund (2013). Women, work, and the economy: Macroeconomic gains from gender equity. IMF Staff Discussion Note.

Johnsen, G. J., \& McMahon, R. G. (2005). Owner-manager gender, financial performance and business growth amongst SMEs from Australia's business longitudinal survey. International Small Business Journal, 23(2), 115-142.

Koellinger, P. (2008). Why are some entrepreneurs more innovative than others? Small Business Economics, 31(1), 21-37.

Koellinger, P., Minniti, M., \& Schade, C. (2013). Gender differences in entrepreneurial propensity. Oxford Bulletin of Economics and Statistics, 75(2), 213-234.

Koo, K. (2019). Do not change horses: Specialist CEOs enhance innovation. Technology Analysis \& Strategic Management, 31(8), 875-887.

Liberda, B., \& Zajkowska, O. (2017). Innovation and entrepreneurship policies and gender equity. International Journal of Contemporary Management, 16(1), 37-59.

Lichtenthaler, U. (2016). Toward an innovation-based perspective on company performance. Management Decision, 54(1), 66-87.

Lim, S., \& Envick, B. R. (2013). Gender and entrepreneurial orientation: A multi-country study. International Entrepreneurship and Management Journal, 9(3), 465-482.

Liñán, F., Santos, F. J., \& Fernández-Serrano, J. (2011). The influence of perceptions on potential entrepreneurs. International Entrepreneurship and Management Journal, 7(3), 373-390.

Link, A. N. (Ed.). (2017). Gender and entrepreneurial activity. Edward Elgar Publishing.

Link, A. N., \& Link, J. R. (1999). Women in science: An exploratory analysis of trends in the United States. Science and Public Policy, 26(6), 437-442.

Love, J. H., \& Roper, S. (2015). SME innovation, exporting and growth: A review of existing evidence. International Small Business Journal, 33(1), 28-48.

Madrid-Guijarro, A., García-Pérez-de-Lema, D., \& Van Auken, H. (2013). An investigation of Spanish SME innovation during different economic conditions. Journal of Small Business Management, 51(4), 578601.

Mahmutaj, L. R., \& Krasniqi, B. (2020). Innovation types and sales growth in small firms evidence from Kosovo. The South East European Journal of Economics and Business, 15(1), 27-43.

Manolova, T. S., Carter, N. M., Manev, I. M., \& Gyoshev, B. S. (2007). The differential effect of men and women entrepreneurs' human capital and networking on growth expectancies in Bulgaria. Entrepreneurship Theory and Practice, 31(3), 407-426.

March, J. G., \& Shapira, Z. (1987). Managerial perspectives on risk and risk taking. Management Science, 33(11), 1404-1418.

Martínez-Ros, E., \& Labeaga, J. M. (2009). Product and process innovation: Persistence and complementarities. European Management Review, 6(1), 64-75.

Marvel, M. R., Lee, I. H. I., \& Wolfe, M. T. (2015). Entrepreneur gender and firm innovation activity: A multilevel perspective. IEEE Transactions on Engineering Management, 62(4), 558-567.

McGuire, G. M. (2000). Gender, race, ethnicity, and networks: The factors affecting the status of employees' network members. Work and Occupations, 27(4), 501-524.

Meuleman, B., Davidov, E., Schmidt, P., \& Billiet, J. (2012). Social location and value priorities. A European-wide comparison of the relation between social-structural variables and human values. Values in Europe. Routledge.

Mínguez-Vera, A., \& Martin, A. (2011). Gender and management on Spanish SMEs: An empirical analysis. The International Journal of Human Resource Management, 22(14), 2852-2873.

Moore, D., \& Buttner, H. (1997). Women entrepreneurs moving beyond the glass ceiling. Sage.

Mukhtar, S.-M. (2002). Differences in male and female management characteristics: A study of ownermanager businesses. Small Business Economics, 18(4), 289-310.

Na, K., \& Shin, K. (2019). Gender effect on a firm's innovative activities in the emerging economies. Sustainability, 11, 1992.

Nählinder, J., Tillmar, M., \& Wigren-Kristoferson, C. (2012). Are female and male entrepreneurs equally innovative? Reducing the gender bias of operationalisations and industries studied. In Andersson, S., Berglund, K., Torslund, J.G., Gunnarsson, E. and Sundin, E. (Eds.), Promoting innovation - policies, practices and procedures. VINNOVA. 
Niederle, M., \& Vesterlund, L. (2007). Do women shy away from competition? Do men compete too much? The Quarterly Journal of Economics, 122(3), 1067-1101.

Nissan, E., Carrasco, I., \& Castaño, M. S. (2012). Women entrepreneurship, innovation, and internationalization. In Galindo, M.A. and Ribeiro, D. (Eds.), Women's entrepreneurship and economics. New perspectives, practices and policies. Springer.

OECD (2006). Economic policy reforms: Going for growth. OECD Publishing.

OECD (2010). Measuring innovation: A new perspective. OECD Publications.

OECD (2017). Policy brief on women's entrepreneurship. European Union. Https://www.oecd.org/cfe/smes/ Policy-Brief-on-Women-s-Entrepreneurship.pdf.

Olivari, J. (2016). Entrepreneurial traits and firm innovation. Eurasian Business Review, 6, 339-360.

Pettersson, K., \& Lindberg, M. (2013). Paradoxical spaces of feminist resistance: Mapping the margin to the masculinist innovation discourse. International Journal of Gender and Entrepreneurship, 5(3), 323-341.

Pittiglio, R., Sica, E., \& Villa, S. (2009). Innovation and internationalization: The case of Italy. The Journal of Technology Transfer, 34(6), 588-602.

Ramadani, V., Abazi-Alili, H., Dana, L. P., Rexhepi, G., \& Ibraimi, S. (2017). The impact of knowledge spillovers and innovation on firm-performance: Findings from the Balkans countries. International Entrepreneurship and Management Journal, 13(1), 299-325.

Reçica, F., Hashi, I., Jackson, I., \& Krasniqi, B. A. (2019). Innovation and the export performance of firms in transition economies: The relevance of the business environment and the stage of transition. International Journal of Entrepreneurship and Small Business, 38(4), 476-506.

Reynolds, P., Bosma, N., Autio, E., Hunt, S., De Bono, N., Servais, I., Lopez-Garcia, P., \& Chin, N. (2005). Global entrepreneurship monitor: Data collection design and implementation 1998-2003. Small Business Economics, 24(3), 205-231.

Robb, A. M., \& Watson, J. (2012). Gender differences in firm performance: Evidence from new ventures in the United States. Journal of Business Venturing, 27(5), 544-558.

Rothwell, R., \& Dodgson, M. (1991). External linkages and innovation in small and medium-sized enterprises. R\&D Management, 21, 125-137.

Sánchez-Báez, E. A., Fernández-Serrano, J., \& Romero, I. (2018). Personal values and entrepreneurial attitude as intellectual capital: Impact on innovation in small enterprises. Amfiteatru Economic Journal, 20(49), 771-787.

Sexton, D. L., \& Bowman-Upton, N. (1990). Female and male entrepreneurs: Psychological characteristics and their role in gender-related discrimination. Journal of Business Venturing, 5(1), 29-36.

Shane, S. (2000). Prior knowledge and the discovery of entrepreneurial opportunities. Organization Science, 11(4), 448-469.

Sirec, K., \& Mocnik, D. (2012). Gender specifics in entrepreneurs' personal characteristics. Journal for East European Management Studies, 17, 11-39.

Sonfield, M., Lussier, R., Corman, J., \& McKinney, M. (2001). Gender comparisons in strategic decisionmaking: An empirical analysis of the entrepreneurial strategy matrix. Journal of Small Business Management, 39(2), 165-173.

Spanish Ministry of Industry, Energy and Tourism (2013). SMEs' statistics: evolution and indicators. Dirección General de Industria y de la Pequeña y Mediana Empresa. Publicaciones del Ministerio de Industria, Energía y Turismo.

Storey, D. (1994). Understanding the small business sector. Routledge.

Strohmeyer, R., \& Tonoyan, V. (2005). Bridging the gender gap in employment growth: On the role of innovativeness and occupational segregation. The International Journal of Entrepreneurship and Innovation, 6(4), 259-273.

Sullivan, D. M., \& Marvel, M. R. (2011). Knowledge acquisition, network reliance, and early-stage technology venture outcomes. Journal of Management Studies, 48(6), 1169-1193.

Taylor, R. N. (1975). Age and experience as determinants of managerial information processing and decision making performance. Academy of Management Journal, 18(1), 74-81.

Teece, D. J. (1996). Firm organization, industrial structure, and technological innovation. Journal of Economic Behaviour \& Organization, 31(2), 193-224.

Teng, B. S. (2007). Corporate entrepreneurship activities through strategic alliances: A resource-based approach toward competitive advantage. Journal of Management Studies, 44(1), 119-142.

Van Gills, A. (2005). Management and governance in Dutch SMEs. European Management Journal, 23(5), 583-589.

Wajcman, J. (2010). Feminist theories of technology. Cambridge Journal of Economics, 34(1), 143-152.

Walters, J., \& McNeely, C. L. (2010). Recasting title IX: Addressing gender equity in the science, technology, engineering, and mathematics professoriate. Review of Policy Research, 27(3), 317-332. 
Wang, G., Holmes, R. M., Jr., Oh, I. S., \& Zhu, W. (2016). Do CEOs matter to firm strategic actions and firm performance? A meta-analytic investigation based on upper echelons theory. Personnel Psychology, 69(4), 775-862.

Watson, J. (2012). Networking: Gender differences and the association with firm performance. International Small Business Journal, 30(5), 536-558.

Watson, J., \& Robinson, S. (2003). Adjusting for risk in comparing the performances of male-and femalecontrolled SMEs. Journal of Business Venturing, 18(6), 773-788.

Weber, C., \& Geneste, L. (2014). Exploring gender-related perceptions of SME success. International Journal of Gender and Entrepreneurship, 6, 15-27.

Wernerfelt, B. (1984). A resource-based view of the firm. Strategic Management Journal, 5(2), 171-180.

World Bank (2011). World development report 2012. Gender equality and development. World Bank.

Zolin, R., Stuetzer, M., \& Watson, J. (2013). Challenging the female underperformance hypothesis. International Journal of Gender and Entrepreneurship, 5(2), 116-129.

Publisher's note Springer Nature remains neutral with regard to jurisdictional claims in published maps and institutional affiliations.

\section{Affiliations}

\section{Alfonso Expósito $^{1} \cdot$ Amparo Sanchis-Llopis $^{2}$ • Juan A. Sanchis-Llopis ${ }^{2,3}$}

1 University of Malaga, Malaga, Spain

2 University of Valencia and ERICES, Valencia, Spain

3 Department of Applied Economics II, Facultad de Economía, Avenida los Naranjos, s/n, 46022 Valencia, Spain 